\title{
Asia's (lack of) Response and Recovery Plans for the Forcibly Displaced
}

\author{
Swikruti Nayak \\ National Law University, Jodhpur \\ Email: swikrutinayak2000@gmail.com
}

\begin{abstract}
The insufficient and unsystematic way Asian states have singularly dealt with the different types of refugee groups living within their borders has drawn much criticism. The contours of all the different refugee crises have been stretched further with the Covid-19 outbreak. However, a common characteristic of this region is the lack of formal initiatives and actions to address the issue of forced displacement by adhering to international principles at the subregional and domestic levels. The descriptive part of this article outlines the national frameworks or the informal procedures of each host country in Asia, to handle the forcibly displaced population. Much of the policy initiatives, let alone actions, are ad hoc in nature, that directs us to finding lasting solutions. In the analytical part of this article, international principles, regional initiatives and contributions of the specialised agencies of the United Nations have been examined. Yet, in order to address the unique challenges faced by Asian states, a framework legislation at the domestic level is found to be the first step for systematically and uniformly dealing with the influx of displaced persons. The issue of forced displacement is not over, it is merely in abeyance. Hence, the conclusion is that a convergence of legal tools at the national, regional and international level is a pressing priority.
\end{abstract}

Key words: Refugees, UNHCR, Asia, Covid-19

\section{INTRODUCTION}

Since long, forced displacement has been a human rights and development concern in Asia. However, a recurring characteristic of this region is the scrupulous avoidance of nation states to formulate a comprehensive framework legislation for it. The human rights situation in Afghanistan, Myanmar and Syria - all Asian countries which are among the top sources of refugee population, is far from being improved, because of which certain groups have little to no choice about their displacement. Asian countries are one of the largest refugee-hosting countries. All together, they host 4.4 million refugees and asylum seekers, 2.9 million internally displaced persons (IDP), 
2.3 million stateless persons and approximately 84,000 returnees. ${ }^{1}$ According to the United Nations High Commission on Refugees (UNHCR), a 'refugee' is someone who has fled war, violence, conflict or persecution and has crossed an international border to find safety in another country. ${ }^{2}$ An internally displaced person (IDP) is someone who has not crossed the state's border to find safety. ${ }^{3}$ An 'asylum-seeker' is someone who hasn't been legally recognised as a refugee as their request for sanctuary is yet to be processed. ${ }^{4}$ Statelessness is accorded to someone who is not considered to be a national under the operation of law of any country. ${ }^{5}$ Throughout the remainder of this article, wherever observations have been made with respect to refugees, asylum seekers, IDPs, stateless persons and returnees - all of whom are covered under the UNHCR mandate, the author has referred to them collectively as "forcibly displaced".

This article seeks to examine the prospects of resolving the challenges faced by the forcibly displaced in Asia. The challenges in the Asia-Pacific region (covers countries such as USA, UK, Netherlands and the Oceania region) have not been the focus of this article.

The purpose is to find ways forward in dealing with the ongoing crisis of the forcibly displaced in Asia, considering the widely unaccepted international standards and infrequent discussions at the regional and domestic levels. At first, national legislations or policies of each host country, if any, are identified and this state-wise analysis has been carried out by classifying each country under its respective region. The existing approach of and recent measures as applied by individual states is summarily described to draw out the lack of a framework mechanism to systematically and uniformly deal with the influx of displaced persons. This leads to the analytical part of this article, which looks at legal instruments at the international and regional level that have attempted to address the concern. It examines how commitment to these instruments can be beneficial for states despite their shortcomings. The legal status and living conditions of the forcibly displaced in different host countries, as described in the part preceding this, serve as a reference point for the analysis of the legal instruments. However, the degree of effectiveness of such instruments is proportionally related to the receptiveness of the state. The more stringent and consistent policies established for protecting the forcibly displaced at the domestic level are, greater is the effect of such instruments. Years of handling the influx of the forcibly displaced in a particularly lawless zone has proved to be detrimental to the states. Furthermore, the Covid-19 pandemic is a cautionary tale for them to set things moving.

1 UNHCR Asia-Pacific COVID-19 external update, by UNHCR (2020).

2 United Nations High Commissioner for Refugees, "What is a refugee?", online: UNHCR <https://www.unhcr.org/what-is-a-refugee.html>.

3 United Nations High Commissioner for Refugees, "Internally Displaced People", online: $U N H C R<$ https://www.unhcr.org/internally-displaced-people.html>.

4 United Nations High Commissioner for Refugees, "Asylum-Seekers", online: UNHCR <https://www.unhcr.org/asylum-seekers.html>.

5 United Nations High Commissioner for Refugees, "Statelessness in the United States", online: UNHCR<https://www.unhcr.org/asylum-seekers.html>. 


\section{LEGAL STATUS AND LIVING CONDITIONS OF THE FORCIBLY DISPLACED IN ASIA}

Before moving to analysing their shortcomings and suggesting useful alternatives, it is pertinent to study every host country's mechanism to manage the forcibly displaced within their borders considering international and regional initiatives. The state-wise description covers the domestic legislations, if any, the state's treatment of the forcibly displaced generally and the current situation.

\section{Southeast Asia}

Indonesia: The refugees in Indonesia largely comprise of the Afghans and Rohingyas who are on their way to Australia. ${ }^{6}$ At most, a temporary stay is provided to them. ${ }^{7}$ A legal framework that included refugees under its ambit was the Law No. 6 of 2011 on Immigration. ${ }^{8}$ It classified a person not being a citizen of Indonesia as an 'alien' who would have to face detention if not found with valid travel documents. The Director General of Immigration Regulation of 2010, ${ }^{9}$ provides a more unambiguous reference, by stating that asylum seekers and refugees are under the purview of Indonesian authorities in cooperation with the UNHCR. ${ }^{10}$ However, it is only the 2016 Presidential Regulation, that precisely deals with refugee protection and local integration. ${ }^{11}$ Nevertheless, it ranges broadly by not covering refugees who are already living within its territory and specifying the period of detention. ${ }^{12}$ It entrusts major responsibilities to the local governments. ${ }^{13}$ In practice, it is observed that because of the lack of political will and funding, local governments have not been actively taking care of housing and daily needs of the forcibly displaced. ${ }^{14}$ With onset of the Covid19 pandemic, civil society organisations and specialized agencies of the $\mathrm{UN}^{15}$ are

6 Indonesia hosts over 13, 623 refugees. See UNHCR Indonesia, https://www.unhcr.org/id/en.

7 Graeme Hugo, George Tan \& Caven Napitupulu, "Indonesia as a transit country in irregular migration to Australia" in Marie Mcauliffe \& Khalid Koser, eds, A Long Way to Go: Irregular Migration Patterns, Processes, Drivers and Decision-making (ANU Press, 2017) 167.

8 Articles $1 \& 8$ of the Law on Immigration, 2011.

9 Director General of Immigration Regulation No. IMI-148.UM.08.5 of 2010 on Handling Illegal Immigrants

10 Director General of Immigration Regulation No. IMI-148.UM.08.5 of 2010 on Handling Illegal Immigrants. See Arie Afriansyah \& Eva Achjani Zulfa, "Refugees Resettlement: A Review of Indonesian Laws and Practices" (2018) 8:2 Indonesia Law Review 203-220.

11 Regulation of the President of the Republic of Indonesia No. 125 Year 2016 Concerning the Handling of Foreign Refugees, 2016.

12 Stalemate: Refugees in Indonesia - Presidential Regulation No 125 of 2016, Working Paper, by A Missbach et al, Working Paper (Centre for Indonesian Law, Islam and Society, University of Melbourne, 2018).

13 Ibid.

14 Ibid; Is the 2016 Indonesian Presidential Regulation a potential 'game-changer' on rescue of Rohingya boat refugees? / Kaldor Centre, by Susan Kneebone (Andrew \& Renata Kaldor Centre for International Refugee Law, 2020).

15 IOM, "IOM Ramps Up Response to Covid-19 Pandemic for Refugees in Indonesia", International Organization for Migration (17 April 2020); Alongside the Government of Indonesia, partner organizations and sister UN agencies, UNHCR ensures that refugees are not left behind in COVID-19 response, by Mitra Suryono (UNHCR Indonesia, 2020). 
largely taking up the responsibility to spread awareness about the virus and providing sanitation services. Interestingly, local people were also contributing to the rescue missions for the Rohingya refugees. ${ }^{16}$

Malaysia: There is no coherent legal framework on refugees, ${ }^{17}$ as a result of which, governmental decisions on refugee protection tend to be $\mathrm{ad}$ hoc. Malaysia had displayed open support for the Rohingyas in the beginning of the refugee crisis. $^{18}$ However, it formally announced, in the $36^{\text {th }}$ ASEAN Summit, that Rohingya refugees will no longer be, accepted and provided humanitarian assistance. ${ }^{19}$ There have been protests across Malaysia against the human rights abuses of the Rohingya population living within the country's borders..$^{20}$ Over time, xenophobic attitudes have been adopted towards them, which has been exacerbated by the onset of Covid-19. ${ }^{21}$ The response from the government has not been particularly inclusive, with only select NGOs being able to communicate with the forcibly displaced. ${ }^{22}$

Thailand: Thailand does not have a domestic law regarding refugees. ${ }^{23}$ In 2019 , the Thai Cabinet established a framework, i.e. a screening mechanism for undocumented refugees and immigrants, however, it is yet to be implemented.$^{24}$ Since a long time, asylum seekers have been arrested and detained in overcrowded, unsanitary and prison-like centres. ${ }^{25}$ During the Covid-19 pandemic, refugees have had free access to testing and treatment facilities, however, there has been no guaranteed access to work, liveable housing conditions and sanitation facilities during this time.$^{26}$ NGOs in Thailand are supporting the needs of the refugees by providing risk communications, masks and other hygiene facilities. ${ }^{27}$

16 Rebecca Ratcliffe \& Febriana Firdaus, "Indonesian villagers defy Covid-19 warnings to rescue Rohingya refugees", The Guardian (26 June 2020).

17 Malaysia hosts 177, 940 registered refugees and asylum-seekers, with more than 153,000 from Myanmar. See UNHCR Malaysia, https://www.unhcr.org/en-my/figures-at-a-glance-inmalaysia.html.

18 Christine H Kim, "Challenges to the Rohingya Population in Malaysia”, (10 July 2020), online: CSIS; Thomas Daniel \& Puteri Nor Ariane Yasmin, "The Impact of COVID-19 on Refugees and Asylum Seekers in Malaysia”, (8 October 2020), online: LSE Southeast Asia Blog.

19 PM's Speech at The 36th ASEAN Summit (June 26, 2020), https://www.pmo.gov.my/ 2020/06/speech-at-the-36th-asean-summit/.

20 Piya Sukhani, "The Shifting Politics of Rohingya Refugees in Malaysia”, The Diplomat (10 July 2020).

21 Emily Fishbein, "Fear and uncertainty for refugees in Malaysia as xenophobia escalates", The New Humanitarian (25 May 2020).

22 Natalie Shobana Ambrose, "Malaysia’s Marginalized and Covid-19”, (13 May 2020), online: The Asia Foundation <https://asiafoundation.org/2020/05/13/malaysias-marginalized-and-covid-19/>.

23 Thailand hosts more than 475,000 refugees and asylum-seekers. Rohingya refugees are in majority. See UNHCR Thailand, https://reporting.unhcr.org/thailand.

24 UNHCR, "UNHCR welcomes Thai Cabinet approval of national screening mechanism Thailand", ReliefWeb (26 December 2019).

25 Between a Rock and a Hardplace: Thailand's Refugee Policies and Violations of the Principle of Non-Refoulment, by Amnesty International (2017).

26 Daron Tan \& Manachaya Yankittikul, “A Looming Catastrophe: COVID-19, Urban Refugees, and the Right to Health in Thailand”, (11 May 2020), online: Refugee Law Initiative Blog.

27 ACTED Thailand, "31st March 2020: Refugees in Thailand lead the fight against Covid-19 through mask production”, (1 April 2020); COVID-19 does not stop Thai Church's work on 
Philippines: It is the only country in South-East Asia, which is party to the Convention Relating to the Status of Refugees, 1951 (the "Refugee Convention") and Protocol Relating to the Status of Refugees, 1967 (the "Protocol"). Philippines has a sizeable population of IDPs in Mindanao, ${ }^{28}$ as a result of years of internal conflict between political groups. A legislation has not been implemented pursuant to its obligation under the 1951 Convention, however, the government has provided protection to the IDPs. ${ }^{29}$ Amid the Covid-19 outbreak, the government is working with UNHCR to provide essential services and PPEs and raising health awareness through campaigns. ${ }^{30}$

\section{South Asia}

Afghanistan: It is the only country in the South-Asia region which is party to the Refugee Convention and the Protocol. Afghanistan is the world's second-largest source of refugees. ${ }^{31}$ Over thirty-five years of foreign invasion and armed conflicts with insurgents has virtually left Afghanistan with little to no medical facilities and infrastructure to deal with the people forced to flee the country and the returnees. ${ }^{32}$ The withdrawal of the United States Armed Forces from Afghanistan by August of 2021 was compounded with the effects of the pandemic. ${ }^{33}$ Apart from the evacuees to the United States (US) and Europe, thousands of Afghans who are at risk of persecution are internally displaced or seeking refuge in neighbouring countries. ${ }^{34}$

Pakistan: The world's second-largest refugee-hosting country, ${ }^{35}$ Pakistan, does not have a legal framework for refugees. ${ }^{36}$ Tripartite agreements between Pakistan, Afghanistan and UNHCR and bilateral co-operations with UN and Afghanistan, have led to creation of policies related to refugee protection and repatriation. ${ }^{37}$ Refugees and asylum seekers are supposed to get citizenship rights as Pakistan grants birth-right

behalf of migrants and refugees, AsiaNewsit, "COVID-19 does not stop Thai Church's work on behalf of migrants and refugees”, (7 July 2020).

28 Philippines hosts more than 370,000 IDPs in the Mindanao region. See UNHCR Philippines, https://www.unhcr.org/ph/19591-jun2020-enews-mindanao.html.

29 Ibid; UNHCR Philippines, https://www.unhcr.org/ph/11886-9wavesrefugees.html.

30 UNHCR Philippines, "Stay and Deliver: Responding to COVID-19 in the Philippines", (6 July 2020).

31 There are more than 2.5 million forcibly displaced outside Afghanistan. See Afghanistan, UNHCR, https://www.unhcr.org/en-us/afghanistan.html.

32 Grant Farr, "Afghan Refugees and the Coronavirus Pandemic", (26 May 2020), online: $\boldsymbol{E}$ International Relations.

33 Lindsay Maizland, "Where Will Afghan Refugees Go?”, (8 September 2021), online: Council on Foreign Relations.

34 After the Airlift: Protection for Afghan Refugees and Those Who Remain at Risk in Afghanistan, by Hardin Lang et al (Refugees International, 2021).

35 Pakistan hosts more than 1.4 million Afghan refugees. See Pakistan, UNHCR, https://reporting.unhcr.org/pakistan.

36 Muhammad Zubair, Muhammad Aqeel Khan \& Muzamil Shah, “Analysis of Pakistan’s Policy Towards Afghan Refugees: A Legal Perspective” (2019) 4:3 Global Political Review 28-38.

37 Pakistan situation of Afghan refugees: country of origin information report., by European Asylum Support Office (2020). 
citizenship. ${ }^{38}$ However, the ground reality remains that thousands of Afghan refugees, including children born on Pakistan soil, have been denied asylum. In fact, the country has given effect to unlawful forced returns of refugees and asylum seekers en masse ${ }^{39}$ During the Covid-19 pandemic, special initiatives by the government for the concerned population have not been implemented and UNHCR's assistance is turning out to be inadequate, because of which the country is in need of urgent financial support. ${ }^{40}$ A perpetual uncertainty exists, as neither does Afghanistan have the political and economic conditions to harbour returnees nor does Pakistan have the willingness to support refugees. ${ }^{41}$

Bangladesh: Since a long time, Bangladesh has performed its humanitarian obligations and followed the principle of non-refoulement for Rohingya refugees living within its territories. ${ }^{42}$ This has been done, even without a legal framework regarding refugees being in place. ${ }^{43}$ During the Covid-19 pandemic, Cox's Bazar was declared as a high risk area due to the significant amount of cases it had. However, the infection spread within the refugee camps has been limited." This is because of the comprehensive actions taken by the government along with UNHCR and its partners when the very first case was reported such as providing trained healthcare workers, building isolation centres and raising awareness about the virus. ${ }^{45}$

Nepal: Nepal has been generous in hosting a large number of refugees, especially from Bhutan. ${ }^{46}$ It does not have a domestic framework, and co-operates with the UNHCR for conducting refugee status determination (RSD). $e^{47}$ Although many refugees continue to face resettlement challenges ${ }^{18} \mathrm{Nepal}$ is the first country in Asia that has started vaccinating its refugee population for Covid-19. ${ }^{49}$

38 The Pakistan Citizenship Act, \$4 1951.

39 Zuha Siddiqui, "For Afghan Refugees, Pakistan Is a Nightmare-but Also Home”, (9 May 2019), online: Foreign Policy.

40 Aamir Latif, “COVID-19: Afghan refugees in Pakistan seek world's help”, (3 March 2020), online: Anadolu Agency.

41 Lisa Schlein, "COVID-19, Insecurity Slow Afghan Refugee Returns From Pakistan and Iran”, VOA (18 November 2020); Themrise Khan, "Stateless millions", Dawn.com (26 November 2019).

42 Bangladesh hosts more than 8 lakh Rohingya refugees from Myanmar. See Bangladesh, UNHCR, https://reporting.unhcr.org/bangladesh; Nour Mohammad, "Refugee Protection Under the Constitution of Bangladesh: A Brief Overview” (2012) 39 Ref watch 141-156.

43 Ibid.

44 Rodion Ebbighausen, "In Rohingya refugee camps, coronavirus is under control - for now", Deutsche Welle (19 June 2020).

45 Ibid.

46 Submission by the United Nations High Commissioner for Refugees for the Office of the High Commissioner for Human Rights' Compilation Report, Universal Periodic Review: 2nd Cycle, 23rd Session, by Nepal, Universal Periodic Review: 2nd Cycle, 23rd Session (UNHCR, 2015).

47 Ibid.

48 Bipin Ghimere, “A 'successful' refugee resettlement programme: the case of Nepal”, (February 2017), online: Forced Migration Review.

49 UNHCR Aia Pasific, "In a first in Asia Pacific, refugees in Nepal receive vaccinations against COVID-19”, (19 March 2021), online: UNHCR. 
India: India does not have a domestic law regarding refugees. ${ }^{50}$ The Foreigners Act, 1946, and the Foreigners Order, 1948 are the only legal instruments that deal with foreigners and affirmatively allow the government to restrict their movement. ${ }^{51}$ In fact, according to the Citizenship (Amendment) Act, 2019, Hindus, Sikhs, Buddhists, Jains, Parsis, and Christians having come to India from Pakistan, Afghanistan, or Bangladesh before 2014 are not 'illegal migrants' and will be granted citizenship, leaving Muslims outside its ambit. ${ }^{52}$ India has selectively granted refugee status to certain groups of asylum seekers. ${ }^{53}$ On one hand, some sort of financial and strategic support is available to Tibetan and Sri Lankan refugees. ${ }^{54}$ On the other hand, Afghan and Rohingya refugees are neither recognized nor have they received any services from the government, even during the Covid-19 pandemic. ${ }^{55}$ Instead, UNHCR and its local partners are providing essential support including sanitation services to the refugee centres in India. ${ }^{56}$

\section{Central Asia}

About thirty years ago the Soviet Union was dissolved, which created five countries in Central Asia. This break-up of Russia left millions of people stateless. Kazakhstan, Kyrgyzstan, Tajikistan, Turkmenistan, and Uzbekistan had approximately 60 million people without citizenship. ${ }^{57}$ Moreover, a civil war in Tajikistan caused thousands to seek asylum in Afghanistan and neighbouring countries in Central Asia. ${ }^{58}$ However, over the years, progress has been made to end statelessness in the region. Kazakhstan $^{59}$ and Uzbekistane ${ }^{60}$ have amended their national laws to allow thousands of stateless people to be eligible for citizenship. In 2019, Kyrgyzstan became the first country to end statelessness. ${ }^{61}$

50 India hosts 35,000 refugees and asylum seekers from Afghanistan and Myanmar. Smaller groups of refugees come from Sri Lanka, Somalia, Tibet, Yemen, Syria and some African countries. See UNHCR India, https://reporting.unhcr.org/node/10314?y=2019\#year.

51 Bhairav Acharya, "The Future of Asylum in India: Four Principles to Appraise Recent Legislative Proposals" (2016) 9:3-4 NUJS Law review at 183-186.

52 The Citizenship Amendment Bill, Bill No. 370 of 2019 (Jan. 10, 2020), \$2.

53 Acharya, supra note 51 at 184; Arjun Nair, "National Refugee Law for India: Benefits and Roadblocks" (2007) 4 Institute of Peace and Conflict Studies 14.

54 Acharya, supra note 51 at 184; Nair, supra note 53.

55 Dharika Athray, "The plight of refugees in India during COVID19", (7 July 2020), online: Observer, Research Foundation (ORF).

56 Roshni Shankar \& Prabhat Raghavan, "The Invisible Crisis: Refugees and COVID-19 in India" (2020) UNSW Law Sydney \& Kaldor Centre.

57 Uuriintuya Batsaikhan \& Marek Dabrowski, "Central Asia-twenty-five years after the breakup of the USSR” (2017) 3 Russian Journal of Economics 296-320.

58 VOICES ON CENTRAL ASIA, "Refugees from Central Asia and in Central Asia", (27 May 2020).

59 UNHCR India, "Kazakhstan amends laws to ensure universal birth registration and prevent childhood statelessness", (26 December 2019).

60 euronews, "UN hails Uzbekistan's move to end statelessness for 50,000 people”, (5 May 2020).

61 United Nations High Commissioner for Refugees, "Kyrgyzstan ends statelessness in historic first", (4 July 2019), online: UNHCR. 
Although, Russia has acceded to the Refugee Convention and the Protocol, its domestic law, the Law on Refugees 1997 does not comply with the international standards in many ways and has been defunct. ${ }^{62}$ Indeed, the Law on Refugees defines the term 'refugees' in a manner identical to the Refugee Convention and grants the right to education, work and medical facilities to those accorded this status. ${ }^{63}$ However, due to administrative burdens and selective application of the law by authorities, asylum seekers remain in uncertainty and are denied the guaranteed benefits. ${ }^{64}$ At most, a temporary asylum is granted since the refugee status is valid for only three years. Over the years, the number of asylum seekers registered as refugees has significantly dropped. ${ }^{65}$ With the on-going Covid-19 pandemic, refugees in Russia are finding it difficult to buy food and receive medical aid as assistance from NGOs is falling short. ${ }^{66}$ In Tajikistan, UNHCR is providing assistance including cash assistance, however getting access to regular health services has been difficult. ${ }^{67}$

\section{East Asia}

North Korea: For North Korean refugees, border crossing is regulated under a strict framework. ${ }^{68}$ This is further implemented harshly due to the Covid-19 restrictions. ${ }^{69}$ Under North Korea's Criminal Code, a person who tries to cross the border or a 'defector' is detained in reform institutions, with the possibility of a death sentence. ${ }^{70}$ In fact, people who are forced to flee the country under dire circumstances are treated as political prisoners, who are kept in prisons and detention camps. ${ }^{71}$

China: China is party to the Refugee Convention and the Protocol. To implement its international obligations, certain provisions in the Law on Exit and Entry Administration 2012 are concerned with the treatment of asylum seekers. ${ }^{72}$ However, there is neither a framework for granting a refugee status, nor any application procedure or governing body in place to oversee the settlement and integration of asylum seekers. ${ }^{73}$ During the Covid-19 pandemic, it has provided financial assistance to Palestinian refugees and refugee groups in Kenya, South Sudan

62 Ahoura Afshar, "Refugees in Russia: the Law on Refugees and its Implementation" (2005) 18 Journal of Refugee Studies - J REFUG STUD 468-491 at 468.

63 World Refugee Survey 2007 - Russian Federation, by US Committee for Refugees and Immigrants (2007).

64 Ibid; Afshar, "Refugees in Russia”, supra note 62.

65 Afshar, "Refugees in Russia”, supra note 62.

66 Reuters, "Coronavirus lockdown pushes refugees in Russia to the brink", (24 April 2020).

67 UNHCR Central Asia, "Faced with COVID, Refugees in Tajikistan Struggle to Survive”, (2 July 2020).

68 Jin Woong Kang, "Human Rights and Refugee Status of the North Korean Diaspora” (2013) 9:2 North Korean Review 4-17.

69 Benjamin Katzeff Silberstein, “Assessing North Korea’s COVID-19 Containment and Kim Jongun’s Political Challenges”, (29 May 2020), online: Foreign Policy Research Institute.

70 Human Rights Watch, "North Korea Harsher Policies against Border-Crossers”, (March 2007).

71 Ibid.

72 Lili Song, "China and the International Refugee Protection Regime: Past, Present, and Potentials" (2018) 37:2 Refugee Survey Quarterly 139-161.

73 Ibid. 
and Tanzania. ${ }^{74}$ Yet, at home, China has prohibited the escapees from crossing the border and in turn repatriated them to North Korea, to be once again imprisoned in inhumane conditions. ${ }^{75}$ Along with a strict border surveillance, the government strictly controls NGOs and Chinese citizens that try helping North Korean refugees. ${ }^{76}$

Japan: Japan is another country in East Asia that has ratified the Refugee Convention and the Protocol. Similar to China, Japan's contribution to mitigate the crisis internationally is in contrast with its approach, domestically. The approval rate of refugees in Japan is one of the lowest in the world, i.e. 1\%. The country's attitude towards refugees has created misconceptions, with their status largely remaining unknown. ${ }^{78}$ The Immigration Bureau is responsible for handling asylum requests, and is known to detain refugees in prison-like conditions. ${ }^{79}$ During this pandemic, Japan has been responsive to funding requests made by UNHCR. ${ }^{80}$ However, the country has not been very receptive to the asylum seekers, mostly consisting of the Rohingyas ${ }^{81}$, within its territory. ${ }^{82}$ Majority of the asylum seekers have been detained by immigration authorities. For the NGOs and volunteer groups, retrieving information about the conditions of detainees and raising funds for them has been difficult during this time..$^{83}$

South Korea: South Korea's policies towards North Korean refugees is largely dependent on political will, while it has restrictionist refugee policies in place for other groups of refugees. ${ }^{84}$ In South Korea, all accepted refugees undergo a social familiarisation program to enable resettlement, albeit few instances where they have faced stigma. ${ }^{85}$ It is the only country in East Asia that passed a bill for the protection of asylum seekers and refugees called the Act on the Status and Treatment of

74 Lili Song, "Anywhere but here? China's response to refugee protection during COVID-19", (9 March 2021), online: Open Democracy.

75 Helen Regan \& Jake Kwon, "China is cracking down on North Korean defectors, activists say", CNN (21 June 2019).

76 Kang, supra note 68.

77 More than 10,000 applications for refugee status are pending, with Rohingyas in majority and smaller populations from other Asian and African countries. See nippon.com, "Japan Accepts Far Fewer Refugees than G7 Peers”, (14 May 2019).

78 SeeJapan Association for Refugees, https://www.refugee.or.jp/en/refugee/.

79 Ibid.

80 UNHCR, UNHCR welcomes the Government of Japan's contribution towards COVID-19 responses in Iraq.

81 Japan Factsheet, by UNHCR (2020).

82 Mariko Tamura, "Asylum seekers in Japan face battle for survival in time of coronavirus", The Japan Times (27 June 2020).

83 Rosa Barbaran \& David H Slater, "If the virus gets in, it will spread like wildfire", The Japan Times (4 May 2020); Laksmi Wijayanti, "Protecting Refugees in The Covid-19 Pandemic Era”, (8 July 2020), online: Savy Tokyo.

84 Shin wha Lee, "South Korea's Refugee Policies: National and Human Security Perspectives" in C Hernandez et al, eds, Human Security and Cross-Border Cooperation in East Asia (Palgrave Macmillan, 2019); Se Jin Kim, Failing to Protect Refugees: South Korea’s Dismal Global Ranking (East Asia Foundation, 2019).

85 Dr Nobert Eschborn, "North Korean Refugees in South Korea: Arduous Escape and Difficult Integration” (2014) ISPSW Strategy Series: Focus on Defense and International Security. 
Refugees, 2011. ${ }^{86}$ However, the law which has finally been implemented is substantially different than what was proposed by many parliamentarians and civil society organisations. ${ }^{87}$ It vests unfettered discretionary power with the Ministry of Justice for deciding matters related to the refugee screening process and providing social services. ${ }^{88}$ During the Covid-19 pandemic, the South Korean government has responded to the demands of NGOs. As a result, undocumented migrants and refugees have received testing and treatment facilities without facing the risk of deportation. ${ }^{89}$ The government is also working with the NGOs to disseminate information regarding the health crisis. ${ }^{90}$

Hong Kong: Hong Kong handles asylum requests via its own screening systems and the approval rate is $1 \%$ - the lowest among developed countries. ${ }^{91}$ Lack of transparency in asylum procedures coupled with instances of arbitrary detention, indicates that asylum-seekers and refugees ${ }^{92}$ are not particularly safe in Hong Kong.virgi ${ }^{93}$ During the Covid-19 pandemic, the government has provided monthly assistance to all the refugees. ${ }^{94}$ However, sustenance on a daily-basis is difficult due to the rising prices and unemployment. ${ }^{95}$ Social service providers in Hong Kong ${ }^{96}$ and $\mathrm{UNHCR}^{97}$ have been facing funding problems.

Taiwan: The Act Regarding Hong Kong and Macao Affairs is the governing law, which seeks to provide necessary assistance to asylum seekers from Hong Kong. ${ }^{98}$ People who are protesting against China's proposed national security law, consider Taiwan as their place of refuge if they are forced to flee.ore ${ }^{99} \mathrm{y}$ After the economic

86 Chulhyo Kim, “A Step Forward to Refugee Protection? South Korea’s New Refugee Act” (2012) $2: 11$ at 8,9 .

87 Ibid.

88 Ibid.

89 Myoung-hee Kim, "South Korea's COVID-19 success story”, (30 April 2020), online: The Financial Express.

90 Ibid.

91 Virgin Goethals, "World Refugee Day: Hong Kong's asylum system is unfair, intentionally rigged and lacks humanity", (20 June 2020), online: Hong Kong Free Pres.

92 Hong Kong has 14,000 asylum seekers and 130 requests have been accepted. Majority of them come Vietnam, with small groups from Pakistan, Bangladesh, India and war-torn countries in the West Asia, Africa, South-East Asia. See Refugees in Hong Kong, Branches of Hope, https://branchesofhope.org.hk/about-refugees.

93 Goethals, supra note 91.

94 The Refugee Concern Network, "Refugees in Hong Kong - a community forgotten in the coronavirus crisis”, (21 March 2020), online: Hong Kong Free Press.

95 Laura Westbrook, “Asylum seekers left out of Hong Kong's pandemic relief packages”, South China Morning Post (10 May 2020).

96 The Refugee Concern Network, supra note 94.

97 UNHCR Hong Kong, “UNHCR's global approach to COVID-19: Saving lives and preventing spread”, (4 May 2020).

98 Laws \& Regulations Database of The Republic of China, "Laws and Regulations Regarding Hong Kong \& Macao Affairs”, (2017) at $\$ 18$.

99 The Law of the People's Republic of China on Safeguarding National Security in the Hong Kong Special Administrative Region commenced on 30th June, 2020.Tristan Reynolds, "The Case for Accepting Hong Kong Refugees in Taiwan”, (10 June 2020), online: New Bloom Magazine. 
slowdown due to the coronavirus, Taiwan has become more receptive to refuges from Hong Kong due to the possibility that they may boost the country's economy. ${ }^{100}$

\section{West Asia}

Egypt: Egypt considers itself as a transit country for refugees ${ }^{101}$ travelling to Europe. At most, a temporary stay is provided, with non-uniform policy frameworks for refugee groups residing in its territory..$^{102}$ It co-operates with the UNHCR to ensure that refugees and asylum seekers get equal access to healthcare as the citizens do. ${ }^{103}$ During Covid-19, refugee groups, mostly from Palestine and Syria, are reeling under pre-existing health issues, ${ }^{104}$ job insecurity ${ }^{105}$ and irregular assistance from aid organisations because of governmental restrictions. ${ }^{106}$

Jordan: Jordan lacks a domestic framework regarding refugees, ${ }^{107}$ but it has accepted the rights of the refugees under an MoU signed with UNHCR. By virtue of this MoU, refugees are respected in accordance with the principle of nonrefoulement and are given international protection. ${ }^{108}$ In the past, the government has prevented non-Jordians to work legally, and during the Covid-19 pandemic, refugees have been excluded from the government's social protection programmes. In fact, unemployment among refugees in United Nations Relief and Works Agency for Palestine Refugees in the Near East (UNWRA) camps rose from $50 \%$ to $100 \%$ as a result of the Covid-19 restrictions. ${ }^{109}$ Majority of the refugee population lives below poverty line and relies entirely on international aid for income. Additionally,

100 Anna Fifield, “As Taiwan goes to the polls, Tsai says the choice is democracy or dictatorship", Washington Post (7 January 2020); Yimou Lee, "Hong Kong laws: Taiwan opens office refugees as police make first arrest", The New Daily (1 July 2020).

101 There are 256,632 refugees and asylum-seekers in Egypt, majorly comprising of Palestinian and Syrian refugees. See UNHCR Egypt, https://reliefweb.int/sites/reliefweb.int/files/ resources/UNHCR-Egypt_Fact_Sheet_February_2020.pdf.

102 Katarzyna Grabska, Who Asked Them Anyway? Rights, Policies and Wellbeing of Refugees in Egypt, Forced Migration and Refugee Studies, American University in Cairo, Egypt, DRC on Migration, Globalisation and Poverty, University of Sussex 18-25 (June, 2006); see generally, Kelsey P Norman, “Ambivalence as Policy: Consequences for Refugees in Egypt” (2017) 15 Égypte/Monde arabe 27-45.

103 Health, UNHCR Egypt, https://www.unhcr.org/eg/what-we-do/main-activities/health.

104 Elena Habersky, "Egypt Must Include Refugees in its Covid-19 Response”, (1 May 2020), online: Egyptian Streets.e

105 Elena Habersky, “Egypt's Most Vulnerable and COVID-19”, (13 May 2020), online: The Cairo Review of Global Affairs.

106 Centre for Migration and Refugee Studies, AUC, "How COVID-19 is affecting Egypt's migrants and refugees”, (7 August 2020), online: OECD.

107 Reva Dhingra, "Refugees at Risk in Jordan's Response to COVID-19", Middle East Research and Information Project (9 April 2020).

108 UNHCR \& Government of Jordan, Memorandum of Understanding Between the Government of Jordan and UNHCR (1998).

109 Taylor Luck, “Covid-19 outbreak drains UN budget for Palestinian refugees”, (30 April 2020), online: The National. 
international assistance has been dwindling and refugees are facing an acute shortage of emergency cash to buy food and other necessities. ${ }^{110}$

Lebanon: Lebanon also lacks a domestic framework, but issues temporary residence permits to asylum seekers ${ }^{111}$ under an MoU signed with the UNHCR. ${ }^{112}$ Despite being a party to relevant international treaties, Lebanon has adopted discriminatory attitudes towards refugees under the guise of lockdown measures. ${ }^{113}$ The government has in general, ignored calls for protection. ${ }^{114}$ Majority of the refugee population, including Syrians and Palestinians lives in poverty, and their situation keeps worsening with no access to food and sanitation services. Syrian refugees who do not have residency permits also hesitate to undergo testing and ask for other health services as they fear the risk of deportation. $\mathrm{d}^{115}$ Moreover, UNHCR has not been able to provide sufficient aid to Syrian refugees. ${ }^{116}$ Similar is the case with Palestinian refugees due to the financial challenges faced by UNWRA. ${ }^{117}$

Turkey: Turkey hosts the world's largest refugee population. ${ }^{118}$ As a transit country, Turkey receives millions of irregular migrants, asylum seekers and refugees trying to reach Europe. The Turkish government has maintained a geographic reservation to the Refugee Convention which allows it to recognize only asylumseekers from European countries as refugees. ${ }^{119}$ There are various domestic laws and policies regarding refugee rights and refugee status, which is jointly granted by UNHCR and Turkey. ${ }^{120}$ Accepted refugees are treated as beneficiaries of temporary protection and cannot locally integrate into the country. ${ }^{121}$ Joint action plans between Turkey and EU have also been established, so as to enable the former to manage the refugee crisis. ${ }^{122}$ During the Covid-19 pandemic, Turkey has only granted political

110 UNHCR Jordan, "UNHCR begins distribution of emergency cash assistance, appeals for $\$ 79$ million", (11 May 2020).

111 The country hosts 1.5 million Syrian refugees and 475,000 Palestinian refugees making it the largest concentration of refugees per capita in the world. See Lebanon UNHCR, https://reporting.unhcr.org/node/2520.

112 United Nations High Commissioner for Refugees, "UNHCR Country Operations Plan 2004 Lebanon”, (2004), online: UNHCR.

113 Human Rights Watch, "Lebanon: Refugees at Risk in COVID-19 Response”, (2 April 2020).

114 Ibid.

115 Diana Hodalli, "Syrian refugees in Lebanon more scared of starvation than COVID-19", Deutsche Welle (6 May 2020).

116 Walid Saleh \& Laila Bassam, "Without soap or sanitizer, Syrian refugees face coronavirus threat", Reuters (19 March 2020).

117 Luck, supra note 109.

118 There are 4 million refugees in Turkey, including 3.7 million from Syria. See UNHCR, Turkey Factsheet,

https://reliefweb.int/sites/reliefweb.int/files/resources/UNHCR\%20Turkey\%20General\%20Fact \%20Sheet\%20September\%202020.pdf.

119 Perihan Elif Ekmekci, "Syrian Refugees, Health and Migration Legislation in Turkey" (2017) 19:6 Journal of Immigrant and Minority Health 1434-1441.

120 Ibid.

121 Ahmet İçduygu \& Doğuş Şimșek, "Syrian Refugees in Turkey: Towards Integration Policies", (20 December 2016), online: Turkish Policy Quarterly.

122 Juliette Tolay, "The EU and Turkey's Asylum Policies in Light of the Syrian Crisis" (2014) IAI Global Turkey in Europe Policy Briefs. 
asylum to refugees from Iraq and Syria, leaving Afghan refugees with no- work permit, residence permit or access to healthcare services. ${ }^{123}$ The forcibly displaced are largely dependent on private ${ }^{124}$ and international aid organisations ${ }^{125}$ for healthcare services.

Yemen: Although, Yemen is a signatory to all relevant international treaties that require a commitment to protect refugee rights, it has not been able to convert this commitment into national refugee legislation. ${ }^{126}$ Almost five years of warfare, a destroyed health care infrastructure, overcrowded refugee camps and increasing number of cholera cases has reduced the country's capacity to keep up with the Covid-19 situation. ${ }^{127}$ Thousands of refugees and IDPs in this West Asia's poorest country are surviving days with little food, no water, no sanitation and no medical support. ${ }^{128}$ Due to lack of funding, UNHCR has cut cash assistance and shut down partnerships with Yemeni NGOs. ${ }^{129}$

Iraq: In Iraq, the government is working with UNHCR to ensure that IDPs ${ }^{130}$ and refugees have access to items of basic hygiene. ${ }^{131}$ Access to affordable care for the Afghan refugees in Iran is far from being achieved. ${ }^{132}$ However, the government has taken steps to ensure protection and has requested for emergency funding. ${ }^{133}$

Iran: In East Asia, Iran is the country worst-hit by Covid-19. ${ }^{134}$ This increases the probability of the number of infected people due to the high cross-border movement. However, Iran has taken efforts to include refugees in national systems and is also seeking funds from UNHCR. ${ }^{135}$

123 Rainer Hermann, "Afghan refugees not welcome”, Deutsche Welle (6 March 2020).

124 Rubya Gursoy, "Turkey Turns to NGOs to Fill Gaps in COVID-19 Response for Refugees", The Media Line (19 April 2020).

125 Syrian crisis: WHO's response in and from Turkey, WHO, https:/www.euro.who.int/en/healthtopics/health-emergencies/syrian-crisis/syrian-crisis-whos-response-in-and-from-turkey.

126 Yemen and refugees: progressive attitudes but policy void, by Nesya HB Hughes (Forced Migration Review, 2003).

127 Human Rights Watch, "Yemen: Displaced at Heightened Covid-19 Risk", (22 May 2020).

128 United Nations High Commissioner for Refugees, "Yemen sees fresh displacement after five years of conflict", (27 March 2020), online: UNHCR.

129 Abubakr Al-Shamahi, “Fear and anxiety' as coronavirus rages through Yemen”, ALJAZEERA (24 June 2020).

130 There are more than 1.4 million IDPs in Iraq, with 250,000 refugees being hosted in neighboring countries. See UNHCR, Iraq Refugees, https:/www.unrefugees.org/emergencies/ iraq/\#: : :text=As\%20of\%202019\%2C\%20almost\%202,the\%20Kurdistan\%20Region\%20of\%20I raq; Iraq itself hosts over 300, 000 refugees majority of them belonging to Syria. See ACAPS, Iraq, https://www.acaps.org/country/iraq/crisis/syrian-refugees.

131 Iraq, UNHCR Covid-19 Update, https://reliefweb.int/sites/reliefweb.int/files/resources/UNHCR \%20Iraq\%20\%20COVID-19\%20Update\%20-\%2028APR20.pdf.

132 Ibrahim Salmani, Hamed Seddighi \& Maryam Nikfard, "Access to Health Care Services for Afghan Refugees in Iran in the COVID-19 Pandemic” (2014) Disaster Medicine and Public Health Preparedness 1-2.

133 COVID-19 response in the Islamic Republic of Iran, by UNHCR (2020).

134 Iran is home to over 950,000 Afghan refugees. See UNHCR, Refugees in Iran, https://www.unhcr.org/ir/refugees-in-iran/.

135 UNHCR, supra note 133. 
Israel: In Israel, applications for asylum are made through the Procedure for Handling Political Asylum Seekers. ${ }^{136}$ The applications can either be accepted or be rejected due to lack of credibility in the story of the asylum-seeker and failure to fulfil the conditions of a 'refugee' under the Refugee Convention. ${ }^{137}$ Israel does not accept 'infiltrators' or asylum seekers from enemy States which are Egypt, Jordan, Iraq, Lebanon, Syria, Saudi Arabia and Yemen. ${ }^{138}$ Since 2009, the responsibility to answer asylum requests was shifted from UNHCR to Israel and the country has claimed that it still respects its treaty obligations including the principle of non-refoulement. ${ }^{139}$ During this pandemic, thousands of Palestinian refugees have been laid off. Over a million refugees are facing food shortages due to Israel's occupation and blockade, ${ }^{140}$ and lack of funding from UNWRA. ${ }^{141}$ In fact, continued incursions of the Israeli forces in Palestinian territories is aggravating the humanitarian conditions. ${ }^{142}$

\section{DEVELOPING A SYNERGY BETWEEN THE EXISTING SOLUTIONS}

\section{International Instruments}

International human rights are vital to an individuals' existence-they are inviolable, interdependent, indivisible, and inalienable rights, which are fundamental to human beings. ${ }^{143}$

The Refugee Convention is the foundation of international refugee law and is administered by the UNHCR. It defines the term 'refugee' and establishes the principle of non-refoulement, i.e., "no Contracting State shall expel or return a refugee in any manner whatsoever to the frontiers of territories where his life or freedom would be threatened on account of his race, religion, nationality, membership of a particular social group or political opinion." ${ }^{14}$ In fact, the principle of non-refoulement is part of the customary international law and is thus binding on

136 Government of Israel, Procedure for Handling Political Asylum Seekers in Israel, (2011).

137 Joshua Pex, "Asylum seekers in Israel - determining refugee status", online: Lawoffice.org.il.

138 Prevention of Infiltration (Offences and Jurisdiction) Law, Aug. 26, 1954, https://www.nevo.co.il/law_html/Law01/247_001.html.

139 Government of Israel, supra note 136.

140 Palestinian Centre for Human Rights, https:/www.pchrgaza.org/en/?cat=47.

141 Mohammad Majid, "1 million Palestinians face food shortage in Gaza”, (20 June 2020), online: Anadolu Agency.

142 The Question of Palestine in the times of COVID-19: Position paper on the situation for Palestinian refugees in Jordan, Lebanon, occupied Palestine and Syria, The Arab Renaissance for Democracy and Development (June 2020).

143 Berta E Hernindez-Truyol, "Human Rights through a Gendered Lens: Emergence, Evolution, Revolution” in Kelly D Askin \& Dorean M Koenig, eds, Women and International Human Rights Law: Introduction to Women's Human Rights Issues Volume 1 (Ardsley, N.Y: Transnational Pub Inc, 1998).

144 United Nations High Commissioner for Refugees, The 1951 Refugee Convention (UNHCR) at Article 33. 
even countries that are not part of any human rights treaty. ${ }^{145}$ It was the earliest treaty which established a binding regime of refugee rights. As a new refugee crisis emerged around the world after 1951, the Protocol ${ }^{146}$ was adopted to broaden the applicability of the Refugee Convention. It states that countries which ratify it, agree to abide by the Refugee Convention as well - even if they are not a party to it. ${ }^{177}$ The UNHCR has reiterated that the Refugee Convention and the Protocol are the "centre of the international legal framework for the protection of refugees". ${ }^{148}$ Refugees have the right not to be expelled, ${ }^{119}$ the right not to face penalty for illegal entry into the territory of a Contracting State, ${ }^{150}$ the right to public relief and assistance as is given to the nationals of the Contracting State, ${ }^{151}$ the right to be issued identity and travel documents ${ }^{152}$ and the right to wage earning employment. ${ }^{153}$

The Universal Declaration of Human Rights recognises equal and inalienable rights of all members of the human family. ${ }^{154}$ Article 14 provides the right to seek and to enjoy asylum in other countries from persecution. ${ }^{155}$ To supplement this, the Refugee Convention was formulated to specifically provide for measures in favour of refugees. The human rights treaties formulated later, are providing human rights in general for all members of the human family. However, only certain provisions of such treaties respond to the peculiar circumstances of refugees. Hence, many scholars have suggested that the Refugee Convention is the most effective when rights under it have been extended to or modified by other human rights treaties..$^{156}$

The obligation not to refoul people to the place where they face persecution on one of the grounds mentioned in the Refugee Convention, is reinforced by a multitude of rights guaranteed by the Convention relating to the Status of Stateless Persons, $1954,{ }^{157}$ the 1961 Convention on the Reduction of Statelessness, ${ }^{158}$ the International Covenant on Civil and Political Rights ${ }^{159}$ (ICCPR) along with the

145 James Hathaway, The Rights of Refugees under International Law (Cambridge: Cambridge University Press, 2005) at 363-367.

146 UN General Assembly, "Protocol Relating to the Status of Refugees (606 U.N.T.S. 267, entered into force 4 Oct.1967” (1967) 606 United Nations (Treaty Series) .

147 Ibid at Article 1.

148 Report of the United Nations High Commissioner for Refugees, 1993, by General Assembly, No.12 (A/48/12) (United Nations, 1993) at Addendum, 48th Session, 19(b).

149 United Nations High Commissioner for Refugees, supra note 144 at Article 32.

150 Ibid at Article 31.

151 Ibid at article 23.

152 Ibid at Article 27-28.

153 Ibid at Article 17.

154 United Nations, Universal Declaration of Human Rights (United Nations, 1948) at Preamble.

155 Ibid at Article 14.

156 Tom Clark \& François Crépeau, "Mainstreaming Refugee Rights. The 1951 Refugee Convention and International Human Rights Law" (1999) 17:4 Netherlands Quarterly of Human Rights 389-410.

157 United Nations High Commissioner for Refugees, The 1954 UN Conventions on Statelessness (UNHCR, 1954) entered into force June 6, 1990.

158 United Nations High Commissioner for Refugees, the 1961 UN Conventions on Statelessness (UNHCR, 1961) entered into force Dec. 13, 1975.

159 OHCHR, International Covenant on Civil and Political Rights (1966) Entry into force 23 March 1976. 
Siracusa Principles, adopted by the UN Economic and Social Council in 1984, ${ }^{160}$ the International Convention on the Elimination of All Forms of Racial Discrimination ${ }^{161}$ (CEAD), the International Covenant on Social, Economic and Cultural Rights ${ }^{162}$ (ICESCR), the Convention Against Torture and Other Cruel, Inhuman or Degrading Treatment or Punishment ${ }^{163}$ (CAT)and the Convention on the Rights of the Child ${ }^{164}$ (CRC).

The treatment of refugees may be governed by separate legal frameworks, but they have the same universal rights and fundamental freedoms. ${ }^{165}$ States have the responsibility to ensure basic rights to all individuals within their territory, without distinctions of any kind. ${ }^{166}$ A number of rights are spelled out, once we read the Refugee Convention with the other human rights treaties. For instance, refugees should have protection against renunciation of nationality, if such loss or renunciation or deprivation of nationality results in statelessness. ${ }^{167}$ Stateless persons are to be treated equally as nationals as far as rationing, housing, public education, and public relief are concerned. ${ }^{168}$ Nobody should be made to return to a State where there are substantial reasons for the host country to believe that they would be in danger of being subjected to torture. ${ }^{169}$ States should provide effective protection against discrimination on grounds such as race, colour, language, religion, national or social origin, property, birth or other status. ${ }^{170}$ Such groups have the right to public health, medical care, social security and social services without any distinction on grounds of national or ethnic origin. ${ }^{171}$ In fact, the right to health, guaranteed to non-citizens, is inherent in the principle of non-discrimination. ${ }^{172}$ They should have access to health facilities, goods, and services in sufficient quantity without discrimination, and it should be affordable for all, even the marginalized. ${ }^{173}$ Moreover, a refugee child must be given appropriate protection and humanitarian assistance, regardless of whether they are accompanied by their parent or not. For this purpose, co-operation is

160 UN Commission on Human Rights, The Siracusa Principles on the Limitation and Derogation Provisions in the International Covenant on Civil and Political Rights (1984) E/CN.4/1985/4.

161 OHCHR, International Convention on the Elimination of All Forms of Racial Discrimination (1965) entry into force 4 January 1969.

162 OHCHR, International Covenant on Economic, Social and Cultural Rights (1966) entry into force 3 January 1976.

163 OHCHR, Convention against Torture and Other Cruel, Inhuman or Degrading Treatment or Punishment (1984) entry into force 26 June 1987.

164 General Assembly, The United Nations Convention on the Rights of the Child (CRC) (United Nations, 1989) entered into force on 2 September 1990.

165 General Assembly, A/RES/71/1: New York Declaration for Refugees and Migrants (United Nations, 2016).

166 OHCHR, supra note 162 at Article 2.

167 United Nations High Commissioner for Refugees, supra note 158 at Article 7.

168 United Nations High Commissioner for Refugees, supra note 157 at Article 20-23.

169 OHCHR, supra note 163 at Article 3.

170 OHCHR, supra note 162 at Article 26.

171 OHCHR, supra note 161 at Article 5.

172 OHCHR, supra note 162 at Article 2(2).

173 Office of the United Nations High Commissioner of Human Rights, 22nd Session of Committee on Economic, Social and Cultural Rights, The Right to the Highest Attainable Standard of Health. (2000) at Article 12. 
required with the United Nations and other intergovernmental organizations or NGOs. ${ }^{174}$

The Asian region has the smallest number of state parties to the Refugee Convention and Protocol. Approximately $60 \%$ of the countries mentioned in this article are parties to the Refugee Convention, ${ }^{175}$ albeit very few have declared reservation and more than $80 \%$ of the countries are parties to at least one human rights treaty. As the descriptive part of this article demonstrates, every state is aware of the problem. Not only this, but most of them are also aware of the international obligation to provide protection. State practice also suggests that they accept the principle of non-refoulement. During this pandemic, some of them have co-operated with agencies of UN and local NGOs and granted them access to the areas where the forcibly displaced reside. However, there is no consensus on the fact that they should be made entitled to other human rights too.

The primary responsibility which states carry by ratifying the Refugee Convention is adherence to the principle of non-refoulment. However, it is the additional responsibility which ratification entails, that becomes one of the key reasons behind the hesitancy of Asian states. ${ }^{176}$ Indeed, the Refugee Convention and Protocol might not provide a comprehensive approach to tackle the complexity of forced displacement taking place across borders today, for instance due to climate change. In addition to this imprecise framework, states are not obligated to systematically manage the forcibly displaced. Parties to the Refugee Convention are bound by the principle of non-refoulement, ${ }^{177}$ not the duty to grant asylum. It also does not substantially provide responsibility-sharing provisions, apart from the preamble which acknowledges international co-operation, when the grant of asylum places unduly heavy 'burdens' on certain countries. Thus, in absence of a comprehensive framework that accounts for the varied reasons of displacement and includes a duty to abide by it, states may be hesitant for committing themselves to international obligations when there are unforeseeable refugee movements in Asia.

International law largely emphasises on the importance of imputing a 'status' or 'identity', not on ensuring that all people in the world have basic protection irrespective of their nationality. In other words, international law has not been able to construct a universal language which would provide legal protection to all, generally. ${ }^{178}$ The different groups of forcibly displaced across Asia are fleeing from a

174 OHCHR, Convention on the Rights of the Child (1989) at Article 22 entry into force 2 September 1990.

175 Afghanistan, Cambodia, China, Egypt, Iran, Isreal, Japan, Kazakhstan, Kyrgyzstan, Philippines, South Korea, Tajikistan, Turkey and Yemen.

176 Veerabhadran Vijayakumar, "Critical Analysis of Refugee Protection in South Asia" (2001) 6 Refuge: Canada's Journal on Refugees at 7-8.

177 United Nations High Commissioner for Refugees, supra note 144 at Article 33.

178 See generally, Problems of Refugee Protection in International Law: An Assessment Through the Rohingya Refugee Crisis in India, by Sridhar Dabiru Patnaik \& Nizamuddin Ahmad Siddiqui (Rochester, NY: Social Science Research Network, 2018) at 17-27. In this part, the authors discuss the response of international law to the problem of refugees, particularly Rohingya refugees. The vaguely defined language of international law and an absence of a secondary obligation in case the principle of non-refoulement is violated, are some of the limitations. This 
territory where they are themselves considered as illegal occupants, and most of the territories they enter are not recognising them as refugees. The denial of refugee status, ignorance by countries of their basic human rights and in some countries, differential treatment of refugee groups, remain a deep concern. Other shortfalls of the Refugee Convention include the absence of a framework for IDPs and no consideration for a host country's capacity to assist the forcibly displaced. ${ }^{179}$ Nevertheless, it is the only treaty which is the backbone of all the work done by the UNHCR. The UNHCR monitors the conditions of refugees and works together with the government for providing assistance to them. To the very least, the Refugee Convention provides a framework within which national governments make decisions regarding the people seeking asylum in their country.

Commitment to international obligations might not completely cure the crisis or provide effective assistance to states at all times. However, the fact of the matter is that states who have adhered to these obligations are able to handle the crisis better and have developed better policies for protection, than those who have not. ${ }^{180}$ The US, a party to the Refugee Convention, enacted the Refugee Act of 1980 (the "Refugee Act") to implement its obligations under the Convention. The Refugee Act adopts a definition of a 'refugee' similar to the Refugee Convention and in-line with the principle of non-refoulement, by mandating the Attorney General to withhold deportation of a person who fits the said category. ${ }^{181}$ Under this Act, administrative procedures are established such as filing an application to the United States Citizenship and Immigration Services and its decisions are subject to further review. ${ }^{182}$ Moreover, the Refugee Act has been interpretated and examined by the Supreme Court of the US. ${ }^{183}$ Except the political constraints faced by the US, the Refugee Act has indeed, refined the national framework for the protection of asylum seekers. ${ }^{184}$ Thus, an international framework provides the necessary guidance to build a national framework, which can help states to build a definite and structured mechanism to handle the refugee crisis, especially during a public health emergency. While Kazakhstan and Philippines have devised national policies ${ }^{185}$ specifically for the refugees and not for 'foreigners' or 'illegal migrants', majority of other countries do not have a domestic framework relating to refugee protection. Most of the Asian states have chosen to ignore the international law and are not willing to develop a

can be applied to the situation of all refugee groups in Asia where the severity of the refugee crisis varies from one country to another with no change in the nature of response.

179 For having a general overview about the problems with the Convention, see Joan Fitzpatrick, "Revitalizing the 1951 Refugee Convention” (1996) 9 Harvard Human Rights Journal 229.

180 Veerabhadran Vijayakumar, supra note 176 at 116.

181 the 96th United States Congress, The Refugee Act $1980(2012)$ at 8 U.S.C. $\$ 1253(\mathrm{~h})(1)$.

182 Bassina Farbenblum, "Executive Deference in U.S. Refugee Law: Internationalist Paths Through and Beyond Chevron” (2011) 60:5 Duke Law Journal 1059-1122 at 1071-1072.

183 United States Supreme Court, INS v. Stevic, 467 U.S. 407 (1984); United States Supreme Court,

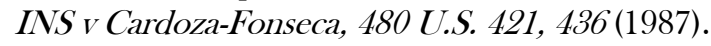

184 David A Martin, The Refugee Act of 1980: A Forlorn Anniversary (Lawfare, 2020).

185 See Part II, pages 3 and 6. 
national law, let alone national policies to help the forcibly displaced combat the pandemic. $^{186}$

State actions for controlling and preventing the spread of coronavirus, do not require infliction of harsh and unprecedented measures on refugees. The word 'pandemic' indicates its global scale of operation, but responses to this pandemic have been implemented through national governments, with each country adopting its own set of public health rules. ${ }^{187}$ Their policies have excluded the forcibly displaced from Covid-19 response plans, evidently in India, Malaysia and Turkey. ${ }^{188}$ By not respecting the principle of non-refoulement, "seas can become graveyards" ${ }^{189}$ which may probably lead to a humanitarian crisis, that states might not be able to handle while recovering from this pandemic.

\section{United Nations Specialised Agencies and Other Bodies}

Within the system of United Nations, various agencies have contributed to the development of a global policy for the forcibly displaced, however, International Organisation for Migration (IOM) and UNHCR have always been the main actors. While IOM lacks a clear normative mandate and its outlay may vary depending on the interests of donor states, UNHCR has been regarded as the principal actor because of its more centralised operations and its mandate under the Refugee Convention. ${ }^{190}$ It plays a supervisory role in overseeing the implementation of the Convention's provisions and states are required to co-operate with its activities. ${ }^{191}$ UNHCR plays multifaceted functions, when it represents the refugees of the world at large, on behalf of the international community. In public international law, it has a derivative personality since its capacity to carry out these functions is largely dependent on funding from states. It has time and again stated, that refugees and asylum-seekers are themselves the victims of violence, rather than being the perpetrators of terror and hence the core principles of refugee protection should not be undermined or ignored by a state's implementation of counter-terrorism measures. ${ }^{192}$

186 See generally Part II, pages 2-12.

187 Jasmine Chia \& Yong Han Poh, “Amid COVID-19 Crisis, Southeast Asia's Migrant Workers Fall Through the Cracks”, The Diplomat (31 March 2020).

188 See Part II, pages 2, 5 and 10.

189 Amnesty International, "COVID-19 is no excuse to sacrifice Rohingya lives at sea", (17 April 2020), online: Amnesty International.

190 Svanhildur Thorvaldsdottir, Ronny Patz, \& Klaus H Goetz, "What Drives Expenditure Allocation in IOs? Problem Pressure, Donor Interests, and Bureaucratic Resource Mobilization in UNHCR and IOM” (2018) International Bureaucracies Reaching Out: Coordination and Cooperation Beyond Organizational Boundaries 37. Not to mention that UNHCR's activities may also be influenced by donor states and both the international organisations are largely dependent on financing by states.

191 United Nations High Commissioner for Refugees, supra note 144 at Article 35.

192 Vincent Cochetel, Deputy Director, Division of International Protection Services (DIPS) UN High Commissioner for Refugees (UNHCR), Terrorism as a Global Phenomenon, UNHCR presentation to the Joint Seminar of the Strategic Committee on Immigration, Frontiers and Asylum (SCIFA) and Committee on Article 36 (CATS) (Jan. 17, 2008) 
Almost every part of Asia which hosts a forcibly displaced population is receiving help from international aid organisations, their local partners and NGOs. The cumulative effort of UNHCR, ${ }^{193}$ UNWRA, ${ }^{194}$ WHO $^{195}$ and UNICEF $^{196}$ has contributed to provision of food, clean water, medical treatment, PPEs, information and communication materials on Covid-19. They have also requested emergency funding for the forcibly displaced in Asia.

In South-East Asian countries, UNHCR, along with assistance from IOM, is allowed to undertake Refugee Status Determination (RSD). In general, long-term protection of refugees, which includes technical and financial assistance, has been largely provided by the UNHCR, while the governments in Indonesia and Malaysia have focussed on providing temporary humanitarian assistance. ${ }^{197}$ It has been particularly difficult for the Office to keep pace with the barrage of applications filed for refugee status, because of which many of the asylum-seekers are compelled to work in the informal sector. ${ }^{198}$ As part of its efforts for combating Covid-19, UNHCR is involved in conducting remote UNHCR ID card renewal verification in Indonesia and protection programmes for women and children in Malaysia. ${ }^{199}$ Philippines has co-operated with the UNHCR to deliver assistance to IDPs and include them in the Covid-19 protection programmes. ${ }^{200}$

Although, none of the countries in South Asia are parties to the Refugee Convention, they have permitted the UNHCR to establish its offices in their territories and co-operated with it. Previously, UNHCR had provided extensive support to the states in this region for repatriating Sri-Lankan Tamil refugees to Sri Lanka and Rohingya refugees to Myanmar. In the 1960-70s, relief operations and vocational training were undertaken for the Tibetan refugees in India and Nepal and, the courts in India have even upheld the basic principles of international refugee law to protect the rights of refugees ${ }^{201}$. During the pandemic, the Indian government has

193 Asia and Pacific - Covid 19 External update, by UNHCR (2020); UNHCR and WHO are also collaborating to strengthen health services for refugees, displaced and stateless people. See WHO, "WHO and UNHCR join forces to improve health services for refugees, displaced and stateless people”, (21 May 2020).

194 UNWRA Responds to Covid-19, https://www.unrwa.org/covid_19; First 100 days and beyond: UNWRA's Health Response to Covid-19 Pandemic, by UNWRA (2020).

195 WHO, "How WHO is supporting refugees and migrants during the COVID-19 pandemic", (20) May 2020).

196 Nicola Brandt, "Migrant, refugee and internally displaced children at the centre of COVID-19 response and recovery", (1 May 2020), online: UNICEF.

197 Reconciling Refugee Protection and Sovereignty in ASEAN Member States: Law and Policy Related to Refugee in Indonesia, Malaysia and Thailand, by Bilal Dewansyah \& Irawati Handayani (Rochester, NY: Social Science Research Network, 2018) at 476-478.

198 Itty Abraham, "Host Communities and Refugees in Southeast Asia" (2020) 35:1 Journal of Social Issues in Southeast Asia 178.

199 Covid-19 External Update (Oct. 28, 2020) https://reporting.unhcr.org/sites/default/files /UNHCR\%20Asia-Pacific\%20COVID-19\%20external\%20update\%2028-10-20.pdf; Covid-19 External Update (Sept. 30, 2020) https://reporting.unhcr.org/sites/default/files/UNHCR $\% 20$ Asia-Pacific\%20COVID-19\%20Update\%20-\%2030SEP20.pdf

200 Ibid.

201 National Human Rights Commission v. State of Arunachal Pradesh, (1996) 1 S.C.C. 742; People's Union for Civil Liberties v. Union of India (1997) S.C.C. 3201. 
continued to provide assistance to the Tibetan and Sr-Lankan Tamil refugees. However, asylum-seekers from Myanmar and Afghanistan who are under the mandate of UNHCR and have been recognised as refugees, are rarely acknowledged by the government, leaving most of them without health care and government relief efforts. ${ }^{202}$ In Nepal, UNHCR has provided cash assistance and taken steps to increase access to distance learning for urban refugee children. ${ }^{203}$ Bangladeshi households have also received cash grants and health benefits from the joint co-operation of the government and UNHCR. ${ }^{201}$

The Almaty Process on Refugee Protection and International Migration (the "Almaty Process") is evidence of the long-standing and active role of UNHCR in Central Asia, albeit few instances of non-corporation from states. ${ }^{205}$ With the onset of the pandemic, UNHCR has devised strategies to increase participation of states and address challenges faced by the stateless and refugees. ${ }^{206}$ On the other hand, China and Japan, even being parties to the Refugee Convention and the Protocol, have not substantially contributed to UNHCR's activities since a long time. China has consistently emphasised on non-interference in matters related to accepting and deporting refugees, because of which UNHCR has not been able to effectively establish itself in the region. ${ }^{207} \mathrm{~s}$

UNHCR's role notably changes in West Asia where the capacity of national authorities is often very limited or in some situations non-existent. In such situations, UNHCR is perceived to play the role of a surrogate state, having its own territory (refugee camps), people and public services. ${ }^{208}$ State responsibility reduces as UNHCR solely subsumes functions which are supposed to be implemented by the state in co-operation with the UNHCR. ${ }^{209}$ However, it must be recalled that UNHCR plays the role of a helping hand and supervisor, and can by no means provide a safe and stable environment necessary for the functioning of basic services, all of which comes under state responsibility. In West Asia, no state can unilaterally or by completely transferring all the responsibilities to the UNHCR solve the issue of forced displacement. ${ }^{210}$ The division of responsibility between the state and UNHCR needs to be carried out with a clearly defined strategy, rather than loosely stating the

202 Hamsa Vijayaraghavan, "Gaps in India's Treatment of Refugees and Vulnerable Internal Migrants Are Exposed by the Pandemic”, (10 September 2020), online: Migration Policy Institute.

203 UNHCR's Covid-19 Update, supra note 199.

204 Ibid.

205 Cynthia Orchard, "The Almaty Process: Improving Compliance with International Refugee Law in Central Asia” (2016) 28:1 International Journal of Refugee Law 55-84 at 67.

206 UNHCR, "The 2019-2021 Regional Strategy for Central Asia”, (July 2020) at 5-6.

207 Song, supra note 72.

208 A surrogate state? The role of $U N H C R$ in protracted refugee situations, Research Paper, by Amy Slaughter \& Jeff Crisp, Research Paper No. 168 (UNHCR, 2009).

209 Volker Turk \& Elizabeth Eyster, "Strengthening Accountability in UNHCR" (2010) 22:2 International Journal of Refugee Law 159-172 at 163-165.

210 "We live in a country of UNHCR" The UN surrogate state and refugee policy in the Middle East, UNHCR Research Paper, by Michael Kagan, UNHCR Research Paper No. 201 (UNHCR, 2011) at 21-22. 
objectives. The MoUs between the UNHCR and Egypt, Jordan and Lebanon, ${ }^{211}$ practically do not oblige the states to comply with the terms of the agreement and undertake responsibilities which lie within their capacities, and because of this shortcoming, the UNHCR has not able to help the governments find a durable solution. ${ }^{212}$ Protection from refoulement and arbitrary detention, and the right to work and physical security, is in the hands of the state. Even functions such as allowing RSD, the right to health services, monetary and nutritional assistance and other types of social services - can be smoothly operated only if the state permits so. ${ }^{213}$

A complete reliance on these international aid organisations is risky because of their limited financial and logistical capacity. Indeed, some countries have responded to the Covid-19 emergency funding appeal of these organisations, ${ }^{214}$ the humanitarian response to the Rohingya population in particular has been generous. ${ }^{215}$ Nonetheless, the scale of the crisis far exceeds the assistance received. UNHCR faces a gradual onset of underfunding which is likely to continue, with drastic consequences on its health, water, shelter capacity and Covid-19 protection related services. ${ }^{216}$ Funds received by it and other organisations are steadily decreasing, however the number of forcibly displaced is rising and the pandemic has amplified their needs. ${ }^{217}$ Situations of being underfunded were faced by the organisations even before the outbreak $^{218}$ and thereafter, such situations are becoming more acute when national governments are exclusively providing assistance to their legal citizens. Particularly, UNWRA has been facing financial challenges since 2018 when contribution from the US was significantly reduced. ${ }^{219}$ There have been instances where UNWRA has had to close down its offices in some areas, which has led to delay in their services. During Covid-19, the Palestinian refugees who are heavily dependent on UNWRA, were receiving irregular services. ${ }^{220}$

Although, organisations of the UN and local NGOs are committed to work for the betterment of the forcibly displaced people in Asian countries, their services are most effective and accessible only when national governments actively cooperate in

211 See Part II, page 11.

212 Kagan, supra note 210.

213 Ibid at 24.

214 Sidhant Sibal, “Amid COVID-19 India donates $\$ 2$ million to UNRWA for Palestinian refugees; UN calls it commendable”, WION (18 May 2020); UNWRA, "Germany disburses EUR 20 Million to Support UNRWA COVID-19 Flash Appeal”, (25 June 2020).

215 Aljazeera, "International donors pledge nearly \$600m to support Rohingya”, (23 October 2020).

216 Harriet Grant, "UN agencies 'broke and failing' in face of ever-growing refugee crisis”, The Guardian (6 September 2015).

217 Vatsal Raj, "Refugees and their host communities in india hard hit by coronavirus lockdown", UNHCR (1 July 2020).

218 Anthony Karumba, "Consequences of severe global funding shortages for refugees and migrants 'all too real', warns UNHCR”, UN NEWS (9 October 2018).

219 UNRWA Financial Crisis: The Impact on Palestinian Employees, by Fiddian Qasmiyeh (MERIP: MIDDLE EAST REPORT) at 33-36.

220 Abby Sewl, "Palestinians in Lebanon say coronavirus help is too little, too late", The New Humanitarian (27 May 2020); Reeda Al-Sabri Halawi, "Human Rights Violations of Refugee Populations in Lebanon Amidst the Covid-19 Outbreak", (12 June 2020), online: Oxford Law Faculty. 
their operations. It is ultimately the national government authorities that have the discretion to enable services of these international aid organisations in their country.

\section{Regional Frameworks}

Protection of the forcibly displaced is heavily dependant on the regional response. Co-operation emerges when countries in a region form an organisation and discuss issues which the region specifically faces. ${ }^{221}$ There are numerous regional initiatives regarding the forcibly displaced in Asia. The most prominent regional organisation in the South-East Asian region is the Association of Southeast Asian Nations (ASEAN). ASEAN's models is built on ensuring sovereignty and territorial integrity for strengthening regional co-operation. ${ }^{222}$ Namely, the doctrine of noninterference is central to ASEAN's model of protecting domestic security. ${ }^{223}$ The issue relating to the forcibly displaced does not become an agenda unless national security is endangered by problems such as human trafficking, smuggling, etc. ${ }^{224}$ ASEAN has previously addressed the violation of rights of migrants, but it had focussed on economic migration and not on forced migration. ${ }^{225}$ Hence, the topic of irregular migration does not specifically include the issue of asylum-seekers or refugees. ${ }^{226}$ The procedure of receiving the forcibly displaced and their local integration has largely been an internal issue for the states, who are addressing the issue based on immigration laws, instead of taking a human-rights based approach. ${ }^{227}$ Countries in the South-East Asian region consider solely UNHCR to be responsible for repatriation and resettlement. They refuse any responsibility beyond providing a temporary and time-bound protection. ${ }^{228}$

On similar lines of state-centrism, the South Asian Association for Cooperation's (SAARC) model is built on territorial integrity and non-interference in the internal affairs of other states ${ }^{229}$ In South Asia, cross-border movements have been considered to be issues relating to internal security which is why states prefer to deal with them

221 Dewansyah \& Handayani, supra note 197.

222 ASEAN, Treaty of Amity and Cooperation in Southeast Asia (1976) at Article 2.

223 Ibid at article 2(c).

224 Dewansyah \& Handayani, supra note 197; To address the issue of transnational crimes, a regional cooperation framework was adopted at the Fourth Bali Regional Ministerial Conference on People Smuggling, Trafficking in Persons and Related Transnational Crime: Co-Chairs' Statement (Mar. 2011) and the Bali Declaration on People Smuggling, Trafficking in Persons and Related Transnational Crime, Mar. 23, 2016 was adopted at the sixth Ministerial Conference.

225 ASEAN, ASEAN Human Rights Declaration (2012) at Article 4; ASEAN, ASEAN Plan of Action for Cooperation on Immigration Matters (2012).

226 Marie McAuliffe, "Resolving Policy Conundrums: Enhancing Humanitarian Protection in Southeast Asia”, (September 2016), online: Migration Policy Institute.

227 Sriprapha Petcharamesree, "ASEAN and its approach to forced migration issues" (2015) 20:2 The International Journal of Human Rights at 173-190.

228 Anja Klug, "Enhancing Refugee Protection in the Asia-Pacific Region: Lack of a Normative Protection Framework" (2013) 107 Proceedings of the ASIL Annual Meeting 358-361.

229 SAARC, Charter of the South Asian Association for Regional Cooperation (1985) at article II. 
bilaterally instead of opting for multilateral channels. ${ }^{230}$ The bilateral route is preferred to escape the scrutiny of the international community. ${ }^{231}$ The degree of human rights guaranteed to the forcibly displaced is proportional to the inter-state or neighbourly relations. ${ }^{232}$

A bilateral approach might not be effective in solving the problem, as every refugee journey is not limited to only one country. Even if it is limited to one region, the hosting country might require assistance from neighbouring countries. ${ }^{233}$ SAARC has excluded bilateral and other contentious issues from its purview, ${ }^{234}$ which further helps member countries in escaping accountability. The flaws of bilateral initiatives in South Asia are evidenced by the repatriation agreements signed between Bangladesh and Myanmar. ${ }^{235}$ From 2017 to 2020, Bangladesh has entered into agreements with Myanmar to fructify repatriation of Rohingya refugees ${ }^{236}$ However, such efforts have consistently failed due to Myanmar's reluctance, and most importantly, absence of safe conditions to repatriate. ${ }^{237}$

In contrast, the Almaty Process, the key regional instrument in Central Asia, has a human rights based approach. As a result of this Process, the Almaty Declaration was established in order to enhance regional cooperation for managing irregular migration. ${ }^{238}$ The Almaty Process is based on ensuring compliance with international refugee law through differentiated processes and procedures related to refugee protection. ${ }^{239}$ It encompasses a Regional Cooperation Framework (RCF) and a Regional Action Plan (RAP) where border protection and statelessness are addressed among other issues. ${ }^{210}$ It lays down a basic foundation for refugee protection, sets achievable goals and works towards progress on sensitive issues. ${ }^{241}$ UNHCR and IOM's contribution is significantly behind states' active participation in the Almaty Process. ${ }^{212}$

Other regional initiatives are the South Asia Declaration on Refugees and Migratory Movements in South Asia, ${ }^{243}$ the Bangkok Principles on the Status and

230 Wei Meng Lim-Kabaa, "Migratory Movement and Refugee Protection in South Asia” (2002) 2 ISIL Year Book of International Humanitarian and Refugee Law 58.

231 Ibid.

232 Ibid.

233 Regional Cooperation on Refugee Protection: The Unanswered Questions, by Madeline Gleeson (Middle East Institute, 2017).

234 SAARC, supra note 229; Myron Weiner, "Rejected Peoples and Unwanted Migrants in South Asia” (1993) 28:34 Economic and Political Weekly 1737-1746.

235 Katie Dock, "Breaking a Cycle of Exodus: Past Failures to Protect Rohingya Refugees Should Shape Future Solutions", (1 June 2020), online: STIMSON.

236 Sultana Yesmin, "Why bilateral initiatives with Myanmar have failed", The Daily Star (21 December 2018).

237 Ibid.

238 IOM, Almaty Declaration 2011 (Almaty, Kazakhstan: UNHCR, 2011).

239 Draft Regional Action Plan (7 Sept 2012) (Annexed to RCF) (RAP)

240 Ibid.

241 Orchard, supra note 205 at 78-81.

242 Ibid.

243 Nafees Ahmad, "Options for Protecting Refugees in South Asia” Harvard International Law Journal. 
Treatment of Refugees, ${ }^{24}$ the Declaration on the Protection of Refugees and Displaced Persons in the Arab World, ${ }^{215}$ the Arab Charter on Human Rights ${ }^{246}$ and the Asia Pacific Refugee Rights Network. ${ }^{247}$ They are not binding on states and their recommendations have been largely ignored.

The past instances of refoulement by states and the present-day ignorance to the plight of the forcibly displaced is evident. That is not to say that national governments have not - provided for one-year temporary protection or enacted policies such as issuing a Presidential Regulation for handling the influx of refugees or established screening mechanisms or given humanitarian relief to different groups of people fleeing violence, human rights abuses from non-state actors and victims of natural disasters. The overall response from Asia, especially South-East Asia, South Asia and Central Asia towards the different group of refugees has been accommodating despite the absence of effective legal frameworks. Nevertheless, its absence results in an arbitrary and discretionary method of deciding which group gets assistance and at what times. This makes it easier for states to implement Covid-19 protection policies and employment recovery plans without including the forcibly displaced or support them in a separate way. As has been the case, even though Asia hosts a third of refugee population in the world, Covid-19 emergency funds created by SAARC ${ }^{218}$ and MERCOSUR, ${ }^{249}$ do not include the forcibly displaced in their relief operations.

An absence of a genuine and effective regional approach to tackle the refugee crisis has led to a non-uniform standard of protection. In fact, absence of a legal framework has led to arbitrariness..$^{250}$ Furthermore, a lack of political will has made states hesitant toward accepting proposals for protection and taking ownership of them, ${ }^{251}$ which leads to having very limited deliberation on the protection of the forcibly displaced. Indeed, there are legitimate concerns of national security and territorial integrity but that should not undervalue concerns of safety and accountability for the human rights violations. Countries in a region or subregion who host the forcibly displaced, are well positioned to understand the continuing crisis of refugees when the same, if not greater health, social and economic problems are being faced by such groups during the pandemic. A successful regional co-operation has its own pre-requisites of well-established diplomatic relationships where countries

244 Asian-African Legal Consultative Organization, Bangkok Principles on the Status and Treatment of Refugees ("Bangkok Principles") (1966).

245 Arabic-Islamic States, Declaration on the Protection of Refugees and Displaced Persons in the Arab World (Regional Refugee Instruments \& Related, 1992).

246 League of Arab States, Arab Charter on Human Rights (1994).

247 The Asia Pacific Refugee Rights Network’s Visions for Regional Protection, June 2014.

248 Elizabeth Roche, "SAARC members warm up to PM Modi’s Covid-19 fund call," Livemint (24 March 2020).

249 Prensa Latina - Latin American News Agency, "MERCOSUR approves emergency fund to face Covid-19”, (27 July 2020).

250 Tapan Kumar Bose, Secretary General of the South Asian Forum for Human Rights in Associated Press, South Asian Groups to Lobby Government for Legal Rights for Refugees (Sept. 9, 1998).

251 Madeline Gleeson, "Where to From Here? Report from the Expert Roundtable on Regional Cooperation and Refugee Protection in the Asia-Pacific" (2016) Andrew \& Renata Kaldor Centre for International Refugee Law. 
decide on the division of responsibility for handling the refugee populations. On the other hand, the lack of regional protection framework results in no consensus between states on burden-sharing which in turn can generate tension between them. ${ }^{252}$

Regional initiatives can create a foundation for states to comply with international obligations and even if they are non-binding on states, persistent efforts of states to participate in these processes and active discussions on such issues may eventually influence state behaviour. ${ }^{253}$ Member states of a regional co-operation are in a position to co-ordinate humanitarian aid, investigate the root causes of forced displacement and collectively press the particular country to stop human rights violation of a group. Thus, it is important to sensitise the governments about the need of a formal and comprehensive approach to solve the issue of the forcibly displaced. This will ensure a balance between border protection and refugee protection. ${ }^{254} \mathrm{~A}$ systematic way of handling the issue will incorporate the interests of both the states and the forcibly displaced. A genuine framework developed by regional cooperation will result in a continuous exchange of information. It will consider the respective financial capacity of states and undertake mechanisms that can be feasibly carried out in the particular region. This can increase the accountability of individual states and enhance the overall protection space available to the forcibly displaced. In a way, states can possibly receive greater funding from other countries and support from the UNHCR. ${ }^{255}$

The International Conference on Central American Refugees, (CIREFCA) convened in 1989, was evidence of a successful regional co-operation. CIREFCA was a regional process customised to the protection needs of refugees in Central America. ${ }^{256}$ To begin with, it expanded the definition of a 'refugee' by including those fleeing generalised conflict. ${ }^{257}$ The seven member countries recognised that although civil wars had ravaged the population of only three countries, its effects were also felt by asylum countries and it was by a concerted efforts of all countries in the region, that a lasting solution to displacement could be found. ${ }^{258}$ The Concerted Plan of Action (CPA), approved in CIREFCA, was a commitment of these countries in Central America to reach a lasting solution by increasing compliance to international norms by including within its fold the principles of the Refugee Convention and the Protocol. ${ }^{259}$ Particularly, governments consulted international agencies and NGOs to

252 Klug, supra note 228.

253 Pia Oberoi, "Regional Initiatives on Refugee Protection in South Asia", (1999) 11 International Journal of Refugee Law 193.

254 Lim-Kabaa, supra note 230.

255 Gleeson, supra note 233.

256 General Assembly, International Conference on Central American Refugees: resolution (UNHCR, 1989). The civil wars in El Salvador, Guatemala and Nicaragua gave rise to 3 million refugees. The other member countries of CIREFCA were Belize, Costa Rica, Honduras and Mexico.

257 Ibid.

258 Regional refugee protection in comparative perspective Lessons learned from the Asia-Pacific, the Americas, Africa, and Europe, by Kate Jastram (Andrew Renata Kaldor Centre for International Refugee Law, 2015).

259 UNHCR, Central Evaluation Section, Review of the CIREFCA Process EVAL/CIREF/14 (1994). 
devise plans, with NGOs being the implementing actors in $60 \%$ of the projects. ${ }^{260}$ Moreover, a UNHCR/UNDP Joint Support Unit, that worked with both the UN and the governments was formed to look over day-to-day operational tasks. ${ }^{261}$ Overall, CIREFCA facilitated a string of meetings at the national, regional and international level to work on and implement plans, report progress made by individual countries and seek international funding. ${ }^{262}$ More than USD 420 million was raised to support the rehabilitation of the forcibly displaced ${ }^{263}$ Indeed, CIREFCA had its shortcomings, however, it is testimony to the fact that countries in a region can collaborate to create a uniform formal procedure, in compliance with international refugee law and with the assistance of local and international aid organisations.

\section{National Frameworks}

Very few host countries in Asia have a domestic framework for determining the status of asylum seekers and providing formal protection. ${ }^{264}$ The fear of triggering the 'pull' factors that attract more number of refugees, possibly transnational criminals, has even led to the weakening of informal refugee protection. ${ }^{265}$ However, this fear should not be used as a pretext for the denial of established rights and protections of the people of concern. ${ }^{266} \mathrm{~A}$ majority of the Asian states such as India, Indonesia, Malaysia, Pakistan, Turkey, etc. consider themselves to be solely transit countries and provide a temporary asylum at most, that too inconsistently.

For systematically managing the situation, a pre-existing domestic framework could alone provide a "permanent solution". ${ }^{267}$ To begin with, the government needs to acknowledge that its country can simultaneously be a short-term and long-term destination for different groups of forcibly displaced. Accordingly, national frameworks should be created, which can also help foster stable alliances with neighbouring countries. It will also place governments in a better position to monitor asylum seekers, determine their antecedents in their country of origin and determine which groups are in most need of international framework. ${ }^{268}$ Additionally, it makes it easier for the UNHCR to co-operate with the states when there is a clear framework relating to refugee rights and the obligations of the state ${ }^{269}$ Countries in Central Asia such as Kazakhstan, Kyrgyzstan and Uzbekistan have been largely successful in ending the status of statelessness under a national framework implemented by active efforts of the government. ${ }^{270}$ National protection frameworks of Philippines and South

260 Jastram, supra note 258.

261 Ibid.

262 Ibid.

263 Ibid; Unlocking Protracted Displacement: Central America's 'Success Story' Reconsidered, by Megan Bradley, Working Paper Series No 77 (12 Refugee Studies Centre, 2011).

264 Indonesia, Russia, South Korea, Turkey and Israel. See pages 2-14.

265 Abraham, supra note 198 at 185-187.

266 Ibid.

267 Jagdish Sharan Verma, Inaugural Address delivered at the Conference on Refugees in SAARC Region: Building a Legal Framework, 3 - 9, New Delhi, 2 May 1997.

268 Surya Sen, "Understanding the importance of a national legislation for refugee protection in India”, (1 July 2017), online: Rights in Exile.

269 Klug, supra note 228.

270 See Part II, pages 5 and 7. 
Korea are also evidence of the fact that such mechanisms facilitate the work of aid organisations. $^{271}$

Uganda has developed a national framework, that is in compliance with the Refugee Convention and the regional framework - the Convention Governing the Specific Aspects of Refugee Problems in Africa of 1969. ${ }^{272}$ It includes an "open door" policy, where all refugees are welcome, irrespective of their ethnicity or nationality. ${ }^{273}$ Refugees have freedom of movement and the right to seek employment. Each refugee family is even given a piece of land for their own agricultural use and refugees of certain nationalities receive "prima facie" protection. Now, there exist some doubts regarding the sustainability of such a generous model of refugee protection. ${ }^{274}$ These include employment concerns of refugees not engaged in agriculture, lack of transparency with international actors about the resources required for the refugees and limited land availability. ${ }^{275}$ However, Uganda's robust framework was the foundation on which it achieved a good amount of funds from the international community and extensive support of the UN ${ }^{276}$ It illustrates that refugees can become contributors to a host country's economy, if given the space and opportunity to do so.

The challenge of the forcibly displaced is not new to Asian states. The devastating impact of the different refugee crisis emanating from the absence of legal obligations is evident. It is perhaps, time to begin implementing policies and programmes in practice, that are tailored to the specific challenges that each state faces. In countries like Indonesia, Israel,Turkey and Asia, there is a domestic framework, but it is yet to be actively implemented. ${ }^{277}$ Such frameworks should be designed for providing refugee rights and not just procedures for determining refugee status. They can be effective when the central government leads the way, rather than the state and local governments managing all the responsibility.

For instance, in light of the exodus of Syrian refugees reaching the borders of EU in 2015, Germany amended a number of asylum related policies legislations, including its Asylum Act. ${ }^{278}$ The Federal Office for Migration and Refugees (BAMF) is the authorising body that handles asylum applications. In addition to the criteria under the Refugee Convention, a refugee status is granted when persecution is caused

271 Ibid.

272 Mark Rook, Identifying Better Refugee Policies for an Evolving Crisis (Honors Theses Philosophy, Politics and Economy, University of Pennsylvania, 2020).

273 The World Bank, "Uganda's Progressive Approach to Refugee Management", (31 August 2016).

274 Tessa Coggio, “Can Uganda’s Breakthrough Refugee-Hosting Model Be Sustained?”, (31 October 2018), online: Migration Policy Institute.

275 Rook, supra note 272 at 29-31.

276 Coggio, supra note 274.

277 See Part II, pages 2, 10 and 12.

278 Maysa Abbas Ayoub, "Understanding Germany's response to the 2015 refugee crisis" (2019) Review of Economics and Political Science; Refugee Protection: German Country Report 13-15, Working Paper, by Valeria Hänsel, Sabine Hess \& Svenja Schurade, Working Paper (GeorgAugust Universität Göttingen, 2019). 
because of one's sexual orientation ${ }^{279}$ or even when it is inflicted by non-state actors ${ }^{280}$. When an asylum application is admitted, a three-year residence permit (which is converted to permanent settlement) is granted, entailing the same benefits as for nationals under the social insurance system. ${ }^{281}$

To accelerate the admittance of asylum applications, the Asylum Package I (2015) and Asylum Package II (2017), along with other legislations, entered into force ${ }^{282}$ In effect, the time period to evaluate asylum applications was reduced to three weeks, in-kind benefits in place of cash benefits were granted, new accommodations were built and German states and municipalities were provided higher reimbursement. ${ }^{283}$ To accelerate integration, there was an increase in employment opportunities and vocational training, with grant of permanent settlement to those who co-operated and demonstrated a willingness to integrate. ${ }^{284}$ Moreover, with the assistance of a national distribution IT-system called 'EASY', Germany allocated asylum seekers arriving at its borders to reception facilities in different German states according to their respective capacities. ${ }^{285}$ As a response to the immediate crisis while accounting for domestic security concerns, Germany refused applicants on suspected grounds of criminality and imposed a temporary ban on entry and residence of applicants from safe countries of origin. ${ }^{286}$

In recent times, high-income countries of East-Asia, like China ${ }^{287}$ and Japan, ${ }^{288}$ have been major contributors of funding asylum-seekers and refugee assistance organisations, but at the same time they have the most rigorous policies in the world for admitting the forcibly displaced. On the other hand, many host countries in West Asia are suffering from an economic crisis and don't have the financial capacity to assist these communities such as Lebanon and Jordan. For dealing with such situations, consistent services from international organisations are needed and for providing consistent services, funding is necessary.

Passing over the problem has neither helped the forcibly displaced nor the states. Instead, acknowledging the existing challenge and thinking through it opens up prospects of managing the crisis, if not completely resolving it. National frameworks of states such as China, Japan, Hong Kong and India, should recognize the status of refugees and acknowledge their rights, instead of treating them as political prisoners, illegal immigrants or illegal migrants. ${ }^{289}$ Conflict and displacement are recognised as

279 The Asylum Act, art. 3(a).

280 Ibid., art. 3(c).

281 Ayoub, supra note 278.

282 Ibid.

283 Ibid.

284 Law Library of Congress, "Germany: Act to Integrate Refugees Enters Into Force”, (15 August 2016).

285 Ayoub, supra note 278.

286 Ibid.

287 Lili Song, "The Power of Giving: China Deepens Involvement in Refugee Affairs" in Sharon Strange et al, eds, Power (ANU Press).

288 Petrice Flowers, "Failure to Protect Refugees? : Domestic Institutions, International Organizations, and Civil Society in Japan” (2008) 34 The Journal of Japanese Studies 333-361.

289 See Part II, pages 5, 7-8. 
public health risks which increases the vulnerability of the population and reduces the system's response. ${ }^{290}$ These public health risks have been supplemented by the onset of the Covid-19 pandemic during which it is being observed that state actions and policies are increasingly becoming exclusionary.

The socio-economic impact of the pandemic has affected everyone, however a more disproportionate effect is faced by the forcibly displaced. Majority of the refugee population work in the informal sector, which has been hardest hit because of restrictions on movement. Unemployment may lead to increased food insecurity, housing insecurity, health care costs and a lack of ability to cope with shocks. ${ }^{291}$ Moreover, their working conditions have worsened because of the increased xenophobia during the outbreak of an infectious disease. ${ }^{292}$ However, inclusion and non-discrimination can reduce the challenges faced by the host countries. In fact, economic inclusion in the post-Covid-19 era can possibly reduce the spread of the virus and stimulate economic recovery which benefits the entire population ${ }^{293}$. Providing the necessary financial support and enabling access to work will produce faster economic recovery in the country. ${ }^{294}$ At the same time, greater economic integration will make such communities more resilient, less dependent on assistance because of having a secured source of income and better livelihood opportunities. Such steps taken by states now, will not only lead to overall development, but also make them better prepared for future times, in case a disaster strikes.

States have pledged under the Sustainable Development Goals 2030, to ensure that "no one will be left behind" and they "endeavour to reach the furthest behind first”. ${ }^{295}$ The WHO, ${ }^{296}$ UNHCR and IOM $^{297}$ have called for inclusion of refugees in the Covid-19 vaccination programmes. The goal is to ensure equitable access, to expand the vaccination coverage, irrespective of a person's citizenship. Nepal began vaccinating refugees within its territory, followed by Lebanon and Jordan. Yet, whether this endeavour to reach the most distressed population has been translated in practice, cannot be ascertained..$^{298}$

290 Chiara Altare et al, "Infectious disease epidemics in refugee camps: a retrospective analysis of UNHCR data (2009-2017)” (2019) 3 Journal of Global Health Reports.

291 Locked Down and Left Behind: The Impact of COVID-19 on Refugees' Economic Inclusion, by Helen Dempster et al (Refugee International Report, 2020).

292 Ibid.

293 Ibid.

294 Ibid.

295 United Nations, “2030 Agenda for Sustainable Development”, (2015).

296 Jozef Bartovic et al, "Ensuring equitable access to vaccines for refugees and migrants during the COVID-19 pandemic" (2021) 99:1 Bulletin of the World Health Organization 3-3A.

297 Teresa Welsh, “'A work in progress': Refugees, migrants must have vaccine access, UN says”, (2 February 2021), online: DEVEX.

298 Human Rights Watch, “Lebanon: Refugees, Migrants Left Behind in Vaccine Rollout”, (6 April 2021). 


\section{CONCLUSION}

For asylum seekers, refugees, IDPs and the stateless population, the response from Asian countries has been weak, much weaker than what is required.

The Refugee Convention and Protocol provides a direction to manage and integrate the forcibly displaced. States in a formal regional co-operation utilise this direction in their specific context. First, human rights and humanitarian concerns of people in need of asylum should be differently treated from concerns of national sovereignty and territorial integrity. Second, responsibility-sharing is greatly enabled since the financial capacities and material concerns of individual states is accounted for. Third, a continuous exchange of information between neighbouring states ensures transparency and accelerates the evaluation of applications. Fourth, continuous discussions influence state behaviour, including, taking a collective action to press the refugee generating state to stop human rights abuses. Fifth, active regional co-operation attracts assistance from international aid organisations and funding from other countries. The UNHCR has played a vital role in Asian states, especially, in West Asia. However, the collaboration with it can be effectively utilised once consistent procedures are established by the state.

Hence, it is on the basis of decisions taken by national governments alone that international obligations, initiatives taken under regional co-operation and services of aid organisations can be accommodated within a country and be made fully effective. Dealing with forced displacement in an ad hoc manner, has neither reduced the number of people of concern nor helped states to manage the needs of the population. Thus, the first step towards dealing with any type of refugee crisis is developing a working framework legislation. Not only this, policies in such frameworks have to necessarily translate in practice. Not one of the solutions discussed in this article, can single-handedly solve the crisis across Asia, but the association of law and policy initiatives at the national, regional and international levels can very well move us closer to a solution.

\section{BIBLIOGRAPHY}

Abraham, Itty, "Host Communities and Refugees in Southeast Asia" (2020) 35:1 Journal of Social Issues in Southeast Asia 178.

Acharya, Bhairav, "The Future of Asylum in India: Four Principles to Appraise Recent Legislative Proposals” (2016) 9:3-4 NUJS Law review.

ACTED Thailand, "31st March 2020: Refugees in Thailand lead the fight against Covid-19 through mask production”, (1 April 2020).

Afriansyah, Arie \& Eva Achjani Zulfa, "Refugees Resettlement: A Review of Indonesian Laws and Practices” (2018) 8:2 Indonesia Law Review 203-220.

Afshar, Ahoura, "Refugees in Russia: the Law on Refugees and its Implementation" (2005) 18 Journal of Refugee Studies - J REFUG STUD 468-491. 
Ahmad, Nafees, "Options for Protecting Refugees in South Asia" Harvard International Law Journal.

Al-Shamahi, Abubakr, "Fear and anxiety' as coronavirus rages through Yemen”, ALJAZEERA (24 June 2020).

Aljazeera, "International donors pledge nearly $\$ 600 \mathrm{~m}$ to support Rohingya”, (23 October 2020).

Altare, Chiara et al, "Infectious disease epidemics in refugee camps: a retrospective analysis of UNHCR data (2009-2017)” (2019) 3 Journal of Global Health Reports.

Ambrose, Natalie Shobana, "Malaysia’s Marginalized and Covid-19”, (13 May 2020), online: The Asia Foundation <https://asiafoundation.org/2020/05/13/malaysias-marginalized-and-covid$19 />$.

Amnesty International, Between a Rock and a Hardplace: Thailand's Refugee Policies and Violations of the Principle of Non-Refoulment, by Amnesty International (2017).

—, "COVID-19 is no excuse to sacrifice Rohingya lives at sea”, (17 April 2020), online: Amnesty International.

Arabic-Islamic States, Declaration on the Protection of Refugees and Displaced Persons in the Arab World (Regional Refugee Instruments \& Related, 1992).

Articles 1 \& 8 of the Law on Immigration, 2011.

ASEAN, ASEAN Human Rights Declaration (2012).

—, ASEAN Plan of Action for Cooperation on Immigration Matters (2012).

—, Treaty of Amity and Cooperation in Southeast Asia (1976).

Asian-African Legal Consultative Organization, Bangkok Principles on the Status and Treatment of Refugees ("Bangkok Principles") (1966).

AsiaNewsit, "COVID-19 does not stop Thai Church's work on behalf of migrants and refugees", (7 July 2020).

Athray, Dharika, "The plight of refugees in India during COVID19", (7 July 2020), online: Observer, Research Foundation (ORF).

Ayoub, Maysa Abbas, "Understanding Germany's response to the 2015 refugee crisis" (2019) Review of Economics and Political Science.

Barbaran, Rosa \& David H Slater, "If the virus gets in, it will spread like wildfire”, The Japan Times (4 May 2020).

Bartovic, Jozef et al, "Ensuring equitable access to vaccines for refugees and migrants during the COVID-19 pandemic" (2021) 99:1 Bulletin of the World Health Organization 3-3A. 
Batsaikhan, Uuriintuya \& Marek Dabrowski, "Central Asia-twenty-five years after the breakup of the USSR” (2017) 3 Russian Journal of Economics 296-320.

Bradley, Megan, Unlocking Protracted Displacement: Central America's 'Success Story’ Reconsidered, by Megan Bradley, Working Paper Series No 77 (12 Refugee Studies Centre, 2011).

Brandt, Nicola, "Migrant, refugee and internally displaced children at the centre of COVID-19 response and recovery", (1 May 2020), online: UNICEF.

Centre for Migration and Refugee Studies, AUC, "How COVID-19 is affecting Egypt's migrants and refugees”, (7 August 2020), online: OECD.

Chia, Jasmine \& Yong Han Poh, “Amid COVID-19 Crisis, Southeast Asia's Migrant Workers Fall Through the Cracks”, The Diplomat (31 March 2020).

Clark, Tom \& François Crépeau, "Mainstreaming Refugee Rights. The 1951 Refugee Convention and International Human Rights Law" (1999) 17:4 Netherlands Quarterly of Human Rights 389-410.

Coggio, Tessa, “Can Uganda's Breakthrough Refugee-Hosting Model Be Sustained?”, (31 October 2018), online: Migration Policy Institute.

Daniel, Thomas \& Puteri Nor Ariane Yasmin, "The Impact of COVID-19 on Refugees and Asylum Seekers in Malaysia”, (8 October 2020), online: LSE Southeast Asia Blog.

Dempster, Helen et al, Locked Down and Left Behind: The Impact of COVID-19 on Refugees' Economic Inclusion, by Helen Dempster et al (Refugee International Report, 2020).

Dewansyah, Bilal \& Irawati Handayani, Reconciling Refugee Protection and Sovereignty in ASEAN Member States: Law and Policy Related to Refugee in Indonesia, Malaysia and Thailand, by Bilal Dewansyah \& Irawati Handayani (Rochester, NY: Social Science Research Network, 2018).

Dhingra, Reva, "Refugees at Risk in Jordan's Response to COVID-19”, Middle East Research and Information Project (9 April 2020).

Dock, Katie, "Breaking a Cycle of Exodus: Past Failures to Protect Rohingya Refugees Should Shape Future Solutions”, (1 June 2020), online: STIMSON.

Ebbighausen, Rodion, "In Rohingya refugee camps, coronavirus is under control for now", Deutsche Welle (19 June 2020).

Ekmekci, Perihan Elif, "Syrian Refugees, Health and Migration Legislation in Turkey" (2017) 19:6 Journal of Immigrant and Minority Health 1434-1441.

Eschborn, Dr Nobert, "North Korean Refugees in South Korea: Arduous Escape and Difficult Integration” (2014) ISPSW Strategy Series: Focus on Defense and International Security.

euronews, "UN hails Uzbekistan's move to end statelessness for 50,000 people", (5 May 2020). 
European Asylum Support Office, Pakistan situation of Afghan refugees: country of origin information report., by European Asylum Support Office (2020).

Farbenblum, Bassina, "Executive Deference in U.S. Refugee Law: Internationalist Paths Through and Beyond Chevron” (2011) 60:5 Duke Law Journal 10591122.

Farr, Grant, "Afghan Refugees and the Coronavirus Pandemic", (26 May 2020), online: E-International Relations.

Fifield, Anna, "As Taiwan goes to the polls, Tsai says the choice is democracy or dictatorship”, Washington Post (7 January 2020).

Fishbein, Emily, "Fear and uncertainty for refugees in Malaysia as xenophobia escalates", The New Humanitarian (25 May 2020).

Fitzpatrick, Joan, "Revitalizing the 1951 Refugee Convention" (1996) 9 Harvard Human Rights Journal 229.

Flowers, Petrice, "Failure to Protect Refugees?: Domestic Institutions, International Organizations, and Civil Society in Japan” (2008) 34 The Journal of Japanese Studies 333-361.

General Assembly, A/RES/71/1: New York Declaration for Refugees and Migrants (United Nations, 2016).

- International Conference on Central American Refugees: resolution (UNHCR, 1989).

- Report of the United Nations High Commissioner for Refugees, 1993, by General Assembly, No.12 (A/48/12) (United Nations, 1993).

- The United Nations Convention on the Rights of the Child (CRC) (United Nations, 1989).

Ghimere, Bipin, “A 'successful' refugee resettlement programme: the case of Nepal”, (February 2017), online: Forced Migration Review.

Gleeson, Madeline, "Where to From Here? Report from the Expert Roundtable on Regional Cooperation and Refugee Protection in the Asia-Pacific" (2016) Andrew \& Renata Kaldor Centre for International Refugee Law.

Gleeson, Madeline, Regional Cooperation on Refugee Protection: The Unanswered Questions, by Madeline Gleeson (Middle East Institute, 2017).

Goethals, Virgin, "World Refugee Day: Hong Kong's asylum system is unfair, intentionally rigged and lacks humanity", (20 June 2020), online: Hong Kong Free Pres.

Government of Israel, Procedure for Handling Political Asylum Seekers in Israel, (2011).

Grant, Harriet, "UN agencies 'broke and failing' in face of ever-growing refugee crisis”, The Guardian (6 September 2015). 
Gursoy, Rubya, "Turkey Turns to NGOs to Fill Gaps in COVID-19 Response for Refugees”, The Media Line (19 April 2020).

Habersky, Elena, "Egypt Must Include Refugees in its Covid-19 Response”, (1 May 2020), online: Egyptian Streets.

—_, "Egypt's Most Vulnerable and COVID-19", (13 May 2020), online: The Cairo Review of Global Affairs.

Halawi, Reeda Al-Sabri, "Human Rights Violations of Refugee Populations in Lebanon Amidst the Covid-19 Outbreak", (12 June 2020), online: Oxford Law Faculty.

Hänsel, Valeria, Sabine Hess \& Svenja Schurade, Refugee Protection: German Country Report 13-15, Working Paper, by Valeria Hänsel, Sabine Hess \& Svenja Schurade, Working Paper (Georg-August Universität Göttingen, 2019).

Hathaway, James, The Rights of Refugees under International Law (Cambridge: Cambridge University Press, 2005).

Hermann, Rainer, “Afghan refugees not welcome”, Deutsche Welle (6 March 2020).

Hernindez-Truyol, Berta E, "Human Rights through a Gendered Lens: Emergence, Evolution, Revolution” in Kelly D Askin \& Dorean M Koenig, eds, Women and International Human Rights Law: Introduction to Women's Human Rights Issues Volume 1 (Ardsley, N.Y: Transnational Pub Inc, 1998).

Hodalli, Diana, "Syrian refugees in Lebanon more scared of starvation than COVID19”, Deutsche Welle (6 May 2020).

Hughes, Nesya HB, Yemen and refugees: progressive attitudes but policy void, by Nesya HB Hughes (Forced Migration Review, 2003).

Hugo, Graeme, George Tan \& Caven Napitupulu, "Indonesia as a transit country in irregular migration to Australia” in Marie Mcauliffe \& Khalid Koser, eds, $A$ Long Way to Go: Irregular Migration Patterns, Processes, Drivers and Decision-making (ANU Press, 2017) 167.

Human Rights Watch, "Lebanon: Refugees at Risk in COVID-19 Response", (2 April 2020).

__, "Lebanon: Refugees, Migrants Left Behind in Vaccine Rollout”, (6 April 2021).

—, "North Korea Harsher Policies against Border-Crossers", (March 2007).

__, "Yemen: Displaced at Heightened Covid-19 Risk", (22 May 2020).

İçduygu, Ahmet \& Doğuş Şimşek, “Syrian Refugees in Turkey: Towards Integration Policies”, (20 December 2016), online: Turkish Policy Quarterly.

IOM, “IOM Ramps Up Response to Covid-19 Pandemic for Refugees in Indonesia”, International Organization for Migration (17 April 2020).

IOM, Almaty Declaration 2011 (Almaty, Kazakhstan: UNHCR, 2011). 
Jastram, Kate, Regional refugee protection in comparative perspective Lessons learned from the Asia-Pacific, the Americas, Africa, and Europe, by Kate Jastram (Andrew Renata Kaldor Centre for International Refugee Law, 2015).

Kagan, Michael, "We live in a country of UNHCR" The UN surrogate state and refugee policy in the Middle East, UNHCR Research Paper, by Michael Kagan, UNHCR Research Paper No. 201 (UNHCR, 2011).

Kang, Jin Woong, "Human Rights and Refugee Status of the North Korean Diaspora” (2013) 9:2 North Korean Review 4-17.

Karumba, Anthony, "Consequences of severe global funding shortages for refugees and migrants 'all too real', warns UNHCR”, UN NEWS (9 October 2018).

Khan, Themrise, "Stateless millions”, Dawn.com (26 November 2019).

Kim, Christine H, "Challenges to the Rohingya Population in Malaysia", (10 July 2020), online: CSIS.

Kim, Chulhyo, "A Step Forward to Refugee Protection? South Korea's New Refugee Act” (2012) 2:11.

Kim, Myoung-hee, "South Korea’s COVID-19 success story”, (30 April 2020), online: The Financial Express.

Kim, Se Jin, Failing to Protect Refugees: South Korea’s Dismal Global Ranking (East Asia Foundation, 2019).

Klug, Anja, "Enhancing Refugee Protection in the Asia-Pacific Region: Lack of a Normative Protection Framework" (2013) 107 Proceedings of the ASIL Annual Meeting 358-361.

Kneebone, Susan, Is the 2016 Indonesian Presidential Regulation a potential 'gamechanger' on rescue of Rohingya boat refugees? / Kaldor Centre, by Susan Kneebone (Andrew \& Renata Kaldor Centre for International Refugee Law, 2020).

Lang, Hardin et al, After the Airlift: Protection for Afghan Refugees and Those Who Remain at Risk in Afghanistan, by Hardin Lang et al (Refugees International, 2021).

Latif, Aamir, “COVID-19: Afghan refugees in Pakistan seek world's help”, (3 March 2020), online: Anadolu Agency.

Law Library of Congress, “Germany: Act to Integrate Refugees Enters Into Force”, (15 August 2016).

Laws \& Regulations Database of The Republic of China, "Laws and Regulations Regarding Hong Kong \& Macao Affairs”, (2017).

League of Arab States, Arab Charter on Human Rights (1994).

Lee, Shin wha, "South Korea's Refugee Policies: National and Human Security Perspectives" in C Hernandez et al, eds, Human Security and Cross-Border Cooperation in East Asia (Palgrave Macmillan, 2019). 
Lee, Yimou, "Hong Kong laws: Taiwan opens office refugees as police make first arrest”, The New Daily (1 July 2020).

Lim-Kabaa, Wei Meng, "Migratory Movement and Refugee Protection in South Asia” (2002) 2 ISIL Year Book of International Humanitarian and Refugee Law 58.

Luck, Taylor, “Covid-19 outbreak drains UN budget for Palestinian refugees", (30 April 2020), online: The National.

Maizland, Lindsay, "Where Will Afghan Refugees Go?”, (8 September 2021), online: Council on Foreign Relations.

Majid, Mohammad, "1 million Palestinians face food shortage in Gaza”, (20 June 2020), online: Anadolu Agency.

Marie McAuliffe, "Resolving Policy Conundrums: Enhancing Humanitarian Protection in Southeast Asia”, (September 2016), online: Migration Policy Institute.

Martin, David A, The Refugee Act of 1980: A Forlorn Anniversary (Lawfare, 2020).

Missbach, A et al, Stalemate: Refugees in Indonesia - Presidential Regulation No 125 of 2016, Working Paper, by A Missbach et al, Working Paper (Centre for Indonesian Law, Islam and Society, University of Melbourne, 2018).

Mohammad, Nour, "Refugee Protection Under the Constitution of Bangladesh: A Brief Overview" (2012) 39 Ref watch 141-156.

Nair, Arjun, "National Refugee Law for India: Benefits and Roadblocks" (2007) 4 Institute of Peace and Conflict Studies 14.

Nepal, Submission by the United Nations High Commissioner for Refugees for the Office of the High Commissioner for Human Rights' Compilation Report, Universal Periodic Review: 2nd Cycle, 23rd Session, by Nepal, Universal Periodic Review: 2nd Cycle, 23rd Session (UNHCR, 2015).

nipponcom, “Japan Accepts Far Fewer Refugees than G7 Peers”, (14 May 2019).

Norman, Kelsey P, “Ambivalence as Policy: Consequences for Refugees in Egypt” (2017) 15 Égypte/Monde arabe 27-45.

Oberoi, Pia, "Regional Initiatives on Refugee Protection in South Asia”, (1999) 11 International Journal of Refugee Law 193.

Office of the United Nations High Commissioner of Human Rights, 22nd Session of Committee on Economic, Social and Cultural Rights, The Right to the Highest Attainable Standard of Health. (2000).

OHCHR, Convention against Torture and Other Cruel, Inhuman or Degrading Treatment or Punishment (1984).

—, Convention on the Rights of the Child (1989).

- International Convention on the Elimination of All Forms of Racial Discrimination (1965). 
—, International Covenant on Civil and Political Rights (1966).

—, International Covenant on Economic, Social and Cultural Rights (1966).

Orchard, Cynthia, "The Almaty Process: Improving Compliance with International Refugee Law in Central Asia” (2016) 28:1 International Journal of Refugee Law $55-84$.

Patnaik, Sridhar Dabiru \& Nizamuddin Ahmad Siddiqui, Problems of Refugee Protection in International Law: An Assessment Through the Rohingya Refugee Crisis in India, by Sridhar Dabiru Patnaik \& Nizamuddin Ahmad Siddiqui (Rochester, NY: Social Science Research Network, 2018).

Petcharamesree, Sriprapha, "ASEAN and its approach to forced migration issues" (2015) 20:2 The International Journal of Human Rights.

Pex, Joshua, "Asylum seekers in Israel - determining refugee status", online: Lawoffice.org.il.

Prensa Latina - Latin American News Agency, "MERCOSUR approves emergency fund to face Covid-19”, (27 July 2020).

Qasmiyeh, Fiddian, UNRWA Financial Crisis: The Impact on Palestinian Employees, by Fiddian Qasmiyeh (MERIP: MIDDLE EAST REPORT).

Raj, Vatsal, "Refugees and their host communities in india hard hit by coronavirus lockdown”, UNHCR (1 July 2020).

Ratcliffe, Rebecca \& Febriana Firdaus, "Indonesian villagers defy Covid-19 warnings to rescue Rohingya refugees", The Guardian (26 June 2020).

Regan, Helen \& Jake Kwon, "China is cracking down on North Korean defectors, activists say”, $C N N$ (21 June 2019).

Regulation of the President of the Republic of Indonesia No. 125 Year 2016 Concerning the Handling of Foreign Refugees, 2016.

Reuters, "Coronavirus lockdown pushes refugees in Russia to the brink", (24 April 2020).

Reynolds, Tristan, "The Case for Accepting Hong Kong Refugees in Taiwan”, (10 June 2020), online: New Bloom Magazine.

Roche, Elizabeth, "SAARC members warm up to PM Modi’s Covid-19 fund call," Livemint (24 March 2020).

Rook, Mark, Identifying Better Refugee Policies for an Evolving Crisis (Honors Theses Philosophy, Politics and Economy, University of Pennsylvania, 2020) [unpublished].

SAARC, Charter of the South Asian Association for Regional Cooperation (1985).

Saleh, Walid \& Laila Bassam, "Without soap or sanitizer, Syrian refugees face coronavirus threat”, Reuters (19 March 2020). 
Salmani, Ibrahim, Hamed Seddighi \& Maryam Nikfard, "Access to Health Care Services for Afghan Refugees in Iran in the COVID-19 Pandemic" (2014) Disaster Medicine and Public Health Preparedness 1-2.

Schlein, Lisa, "COVID-19, Insecurity Slow Afghan Refugee Returns From Pakistan and Iran”, VOA (18 November 2020).

Sen, Surya, "Understanding the importance of a national legislation for refugee protection in India”, (1 July 2017), online: Rights in Exile.

Sewl, Abby, "Palestinians in Lebanon say coronavirus help is too little, too late", The New Humanitarian (27 May 2020).

Shankar, Roshni \& Prabhat Raghavan, "The Invisible Crisis: Refugees and COVID19 in India” (2020) UNSW Law Sydney \& Kaldor Centre.

Sibal, Sidhant, "Amid COVID-19 India donates $\$ 2$ million to UNRWA for Palestinian refugees; UN calls it commendable”, WION (18 May 2020).

Siddiqui, Zuha, "For Afghan Refugees, Pakistan Is a Nightmare-but Also Home", (9 May 2019), online: Foreign Policy.

Silberstein, Benjamin Katzeff, “Assessing North Korea’s COVID-19 Containment and Kim Jong-un’s Political Challenges”, (29 May 2020), online: Foreign Policy Research Institute.

Slaughter, Amy \& Jeff Crisp, A surrogate state? The role of UNHCR in protracted refugee situations, Research Paper, by Amy Slaughter \& Jeff Crisp, Research Paper No. 168 (UNHCR, 2009).

Song, Lili, "Anywhere but here? China's response to refugee protection during COVID-19”, (9 March 2021), online: Open Democracy.

Song, Lili, "China and the International Refugee Protection Regime: Past, Present, and Potentials" (2018) 37:2 Refugee Survey Quarterly 139-161.

Sukhani, Piya, "The Shifting Politics of Rohingya Refugees in Malaysia", The Diplomat (10 July 2020).

Suryono, Mitra, Alongside the Government of Indonesia, partner organizations and sister UN agencies, UNHCR ensures that refugees are not left behind in COVID-19 response, by Mitra Suryono (UNHCR Indonesia, 2020).

Svanhildur Thorvaldsdottir, Ronny Patz, \& Klaus H Goetz, "What Drives Expenditure Allocation in IOs? Problem Pressure, Donor Interests, and Bureaucratic Resource Mobilization in UNHCR and IOM" (2018) International Bureaucracies Reaching Out: Coordination and Cooperation Beyond Organizational Boundaries 37.

Tamura, Mariko, "Asylum seekers in Japan face battle for survival in time of coronavirus”, The Japan Times (27 June 2020). 
Tan, Daron \& Manachaya Yankittikul, “A Looming Catastrophe: COVID-19, Urban Refugees, and the Right to Health in Thailand”, (11 May 2020), online: Refugee Law Initiative Blog.

Teresa Welsh, “'A work in progress': Refugees, migrants must have vaccine access, UN says”, (2 February 2021), online: DEVEX.

the 96th United States Congress, The Refugee Act 1980 (2012).

The Pakistan Citizenship Act, \$4 1951.

The Refugee Concern Network, "Refugees in Hong Kong - a community forgotten in the coronavirus crisis”, (21 March 2020), online: Hong Kong Free Press.

The World Bank, “Uganda's Progressive Approach to Refugee Management”, (31 August 2016).

Tolay, Juliette, "The EU and Turkey's Asylum Policies in Light of the Syrian Crisis" (2014) IAI Global Turkey in Europe Policy Briefs.

Turk, Volker \& Elizabeth Eyster, "Strengthening Accountability in UNHCR” (2010) 22:2 International Journal of Refugee Law 159-172.

UN Commission on Human Rights, The Siracusa Principles on the Limitation and Derogation Provisions in the International Covenant on Civil and Political Rights (1984).

UN General Assembly, "Protocol Relating to the Status of Refugees (606 U.N.T.S. 267, entered into force 4 Oct.1967" (1967) 606 United Nations (Treaty Series)

UNHCR \& Government of Jordan, Memorandum of Understanding Between the Government of Jordan and UNHCR (1998).

UNHCR, Asia and Pacific - Covid 19 External update, by UNHCR (2020).

- Central Evaluation Section, Review of the CIREFCA Process EVAL/CIREF/14 (1994).

—, COVID-19 response in the Islamic Republic of Iran, by UNHCR (2020).

— J Japan Factsheet, by UNHCR (2020).

—_, "The 2019-2021 Regional Strategy for Central Asia”, (July 2020).

—, UNHCR Asia-Pacific COVID-19 external update, by UNHCR (2020).

— UNHCR welcomes the Government of Japan's contribution towards COVID19 responses in Iraq.

_- "UNHCR welcomes Thai Cabinet approval of national screening mechanism - Thailand”, ReliefWeb (26 December 2019).

UNHCR Asia Pasific, "In a first in Asia Pacific, refugees in Nepal receive vaccinations against COVID-19”, (19 March 2021), online: UNHCR. 
UNHCR Central Asia, "Faced with COVID, Refugees in Tajikistan Struggle to Survive”, (2 July 2020).

UNHCR Hong Kong, “UNHCR's global approach to COVID-19: Saving lives and preventing spread”, (4 May 2020).

UNHCR India, "Kazakhstan amends laws to ensure universal birth registration and prevent childhood statelessness”, (26 December 2019).

UNHCR Jordan, "UNHCR begins distribution of emergency cash assistance, appeals for $\$ 79$ million”, (11 May 2020).

UNHCR Philippines, "Stay and Deliver: Responding to COVID-19 in the Philippines”, (6 July 2020).

United Nations High Commissioner for Refugees, "Asylum-Seekers”, online: UNHCR <https://www.unhcr.org/asylum-seekers.html>.

- "Internally Displaced People", online: UNHCR <https://www.unhcr.org/internally-displaced-people.html>.

__, "Kyrgyzstan ends statelessness in historic first”, (4 July 2019), online: UNHCR.

- "Statelessness in the United States", online: UNHCR <https://www.unhcr.org/asylum-seekers.html>.

—, The 1951 Refugee Convention (UNHCR).

—, The 1954 UN Conventions on Statelessness (UNHCR, 1954).

—, the 1961 UN Conventions on Statelessness (UNHCR, 1961).

—, “UNHCR Country Operations Plan 2004 - Lebanon”, (2004), online: UNHCR.

—, "What is a refugee?", online: $U N H C R<$ https://www.unhcr.org/what-is-arefugee.html>.

__, "Yemen sees fresh displacement after five years of conflict", (27 March 2020), online: UNHCR.

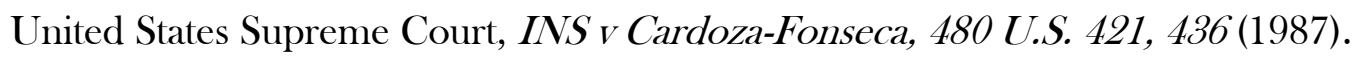

—, INS v. Stevic, 467 U.S. 407 (1984).

UNWRA, "Germany disburses EUR 20 Million to Support UNRWA COVID-19 Flash Appeal”, (25 June 2020).

UNWRA, First 100 days and beyond: UNWRA's Health Response to Covid-19 Pandemic, by UNWRA (2020).

US Committee for Refugees and Immigrants, World Refugee Survey 2007 - Russian Federation, by US Committee for Refugees and Immigrants (2007).

Veerabhadran Vijayakumar, "Critical Analysis of Refugee Protection in South Asia" (2001) 6 Refuge: Canada’s Journal on Refugees. 
Vijayaraghavan, Hamsa, “Gaps in India's Treatment of Refugees and Vulnerable Internal Migrants Are Exposed by the Pandemic", (10 September 2020), online: Migration Policy Institute.

VOICES ON CENTRAL ASIA, "Refugees from Central Asia and in Central Asia”, (27 May 2020).

Weiner, Myron, "Rejected Peoples and Unwanted Migrants in South Asia" (1993) 28:34 Economic and Political Weekly 1737-1746.

Westbrook, Laura, “Asylum seekers left out of Hong Kong's pandemic relief packages”, South China Morning Post (10 May 2020).

WHO, "How WHO is supporting refugees and migrants during the COVID-19 pandemic", (20 May 2020).

Wijayanti, Laksmi, "Protecting Refugees In The Covid-19 Pandemic Era", (8 July 2020), online: Savy Tokyo.

Yesmin, Sultana, "Why bilateral initiatives with Myanmar have failed", The Daily Star (21 December 2018).

Zubair, Muhammad, Muhammad Aqeel Khan \& Muzamil Shah, "Analysis of Pakistan's Policy Towards Afghan Refugees: A Legal Perspective” (2019) 4:3 Global Political Review 28-38.

Swikruti Nayak is a penultimate year student pursuing BB.A. LL.B (Hons.) from National Law University, Jodhpur, India. She is interested in studying public international law, particularly, international human rights law. 